Infectious Diseases in Obstetrics and Gynecology 8:191-197 (2000)

(C) 2000 Wiley-Liss, Inc.

\title{
INFECTIOUS DISEASES SOCIETY FOR
} OBSTETRICS AND GYNECOLOGY

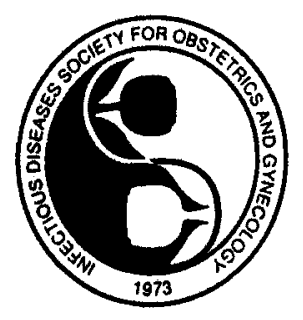

Annual Scientific Meeting and Symposium

August 2-5, 2000

Lake Tahoe, Nevada 

Wednesday, August 2, 2000

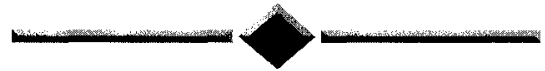

9:00 - 11:00 am IDSOG Council Meeting (Alder A)

11:00 am - 5:00 pm Registration (Lakeside Lobby A)

$1: 00-5: 00 \mathrm{pm}$

Symposium: Viral Vaccines \& Their Impact on Women's Health (Lakeside B)

\begin{tabular}{|c|c|}
\hline $1: 00 \mathrm{pm}$ & $\begin{array}{l}\text { Welcome and Introductions } \\
\text { Stanley A. Gall, MD } \\
\text { Department of Ob/Gyn } \\
\text { University of Louisville } \\
\text { School of Medicine } \\
\text { Louisville, KY }\end{array}$ \\
\hline $1: 05-1: 40 \mathrm{pm}$ & $\begin{array}{l}\text { Varicella Virus: The Disease and the Vaccine } \\
>\text { Ann Gershon, } \mathrm{MD} \\
\text { Columbia University }\end{array}$ \\
\hline $1: 40-2: 15 \mathrm{pm}$ & $\begin{array}{l}\text { Epidemiology of Varicella and Changes in Epidemiology } \\
>\text { Karin Galil, MD } \\
\text { National Immunization Program } \\
\text { CDC }\end{array}$ \\
\hline $2: 15-2: 50 \mathrm{pm}$ & $\begin{array}{l}\text { Post-Marketing Survelliance on Safety Particularly in Pregnancy } \\
>\text { Bob Scharrar, MD } \\
\text { Merck }\end{array}$ \\
\hline $2: 50-3: 10 \mathrm{pm}$ & $\mathrm{Q} \& \mathrm{~A}$ \\
\hline $3: 10-3: 20 \mathrm{pm}$ & Break \\
\hline $3: 20 \mathrm{pm}$ & $\begin{array}{l}\text { Moderator: Emily Koumans, MD, MPH } \\
\text { Centers for Disease Control, STD Prevention Department }\end{array}$ \\
\hline $3: 20-3: 55 \mathrm{pm}$ & $\begin{array}{l}\text { Basic Research in HPV and Vaccine Development } \\
>\text { Kathrin Jansen, Ph.D } \\
\text { Merck }\end{array}$ \\
\hline $3: 55-4: 30 \mathrm{pm}$ & $\begin{array}{l}\text { Varicella Vaccine Policy in Health Care Workers } \\
>\text { David Webber, Ph.D } \\
\text { UNC }\end{array}$ \\
\hline $4: 30-4: 45 \mathrm{pm}$ & $\mathrm{Q} \& \mathrm{~A}$ \\
\hline $4: 45 \mathrm{pm}$ & $\begin{array}{l}\text { Closing } \\
>\text { Stanley A. Gall, MD }\end{array}$ \\
\hline
\end{tabular}

$6: 00-8: 00 \mathrm{pm}$

Welcome Reception (Lakeside Cottage Green) 
Thursday, August 3, 2000

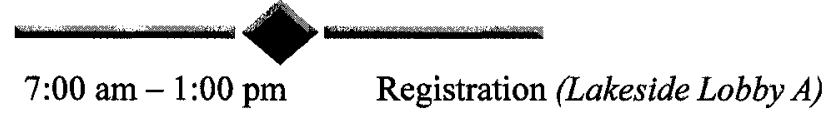

General Sessions (Lakeside B)

8:00 am

$8: 15-9: 00$ am

9:00-10:15 am

$10: 30-10: 45$ am

10:45 am - noon
Welcome - Stanley A. Gall, MD, IDSOG President

Opening Remarks - James A. McGregor, MD, CM Scientific Program Chair

Introduction: David Eschenbach, M.D.

Spastic CP and PVL: New Findings/New Work-up

Rodney Willoughby, MD

Johns Hopkins

Scientific Session I

\begin{tabular}{|c|l|}
\hline $9: 00$ am & $\begin{array}{l}\text { The Effect of Human Neutrophil Peptides (Defensins) on Cyclooxygenase- } \\
\text { 2 Expression and Prostaglandin Production in Human Amnion Cells } \\
\text { Phillip N. Rauk, MD }\end{array}$ \\
\hline $9: 15$ am & $\begin{array}{l}\text { Hydrogen Peroxide-Producing Vaginal Lactobacilli Suppress } \\
\text { HIV-1 Expression In Vitro } \\
\text { Daniel V. Landers, MD }\end{array}$ \\
\hline $9: 30 \mathrm{am}$ & $\begin{array}{l}\text { Peridontal Disease and Spontaneous Preterm Birth } \\
\text { Kim Boggess, MD }\end{array}$ \\
\hline $9: 45$ am & $\begin{array}{l}\text { Administration of Pneumococcal Polysaccharide Vaccine (PNCP) } \\
\text { and The Purified Fusion Protein (PFP-2) for Respiratory } \\
\text { Syncytial Virus to Pregnant Women } \\
\text { W. Paul Glezen, MD }\end{array}$ \\
\hline 10:00 am & $\begin{array}{l}\text { Amniotic Fluid Lipopolysaccharide Binding Protein and Soluble CD14 as } \\
\text { Mediators of The Inflammatory Response in Preterm Labor } \\
\text { Carolyn Gardella, MD }\end{array}$ \\
\hline 10:15 am & $\begin{array}{l}\text { Prenatal Diagnosis of Congenital CMV Infection: Validation } \\
\text { of Low-Level Copy Counts of CMV-DNA in Amniotic Fluid } \\
\text { Analyzed by Quantitative PCR } \\
\text { Neil Silverman, MD }\end{array}$ \\
\hline
\end{tabular}

Break \& Posters (Lakeside A)

Scientific Session II

\begin{tabular}{|c|l|}
\hline 10:45 am & $\begin{array}{l}\text { Molecular Characterization of Recurrent } \\
\text { Vulvovaginal Candidiasis: } \text { A Comparison of Electrophoretic } \\
\text { Karyotyping and Randomly Amplified DNA Fingerprinting } \\
\text { Jack D. Sobel, MD }\end{array}$ \\
\hline $11: 00$ am & $\begin{array}{l}\text { Vaginal Nonoxynol-9 (N-9) Spermicide Use with Intercourse } \\
\text { Dorothy Patton, Ph.D }\end{array}$ \\
\hline $11: 15$ am & $\begin{array}{l}\text { Effect of Vaginal Douching on Vaginal Physiology } \\
\text { David Eschenbach, MD }\end{array}$ \\
\hline $11: 30$ am & $\begin{array}{l}\text { Beta Defensin-1 is Variably Expressed in Cells of Human Amniochorion } \\
\text { Deborah Draper, Ph.D }\end{array}$ \\
\hline $11: 45$ am & $\begin{array}{l}\text { Antimicrobial Protein Produced by Vaginal Lactobacillus Species, } \\
\text { Recovery and Purification } \\
\text { Alla Aroutcheva, MD, Ph.D }\end{array}$ \\
\hline
\end{tabular}



12:00 - 1:00 pm Presidential Guest Lecturer
Charles Helms, M.D, Ph.D
Professor of Medicine
University of Iowa

5:00 pm Scientific Poster Session (Lakeside A)

Interaction and discussion between Poster Presenters and Attendees

Friday, August 4, 2000

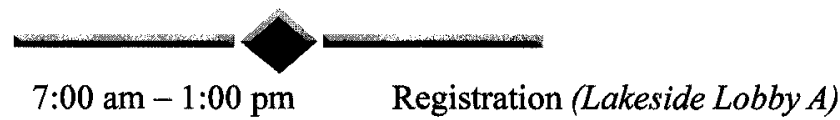

General Sessions (Lakeside B)

8:00-9:00 am

$9: 00-10: 15$ am

$10: 15-10: 30$ am

$10: 30-11: 00$ am

$11: 00 \mathrm{am}$
Moderator: Sharon Hillier, Ph.D

The News from the Rakai (Africa):

Mass Chemoprophylaxis Reduces PTB/LBW but not HIV

Ronald Gray, MD

Maria Wawer, MD

Johns Hopkins

\section{Scientific Session III}

\begin{tabular}{|c|l|}
\hline $9: 00$ am & $\begin{array}{l}\text { Cromolyn Cream for Recalcitrant Idiopathic Vulvar Vestibulitis: } \\
\text { Results of a Placebo-Controlled Study } \\
\text { Paul Nyirjesy, MD }\end{array}$ \\
\hline $9: 15 \mathrm{am}$ & $\begin{array}{l}\text { Patients' and Physicians'Acceptance of Influenza Vaccine in Pregnancy } \\
\text { Neil Silverman, MD }\end{array}$ \\
\hline $9: 30 \mathrm{am}$ & $\begin{array}{l}\text { Pharmacokinetics of Azithromycin in the Term Gravida } \\
\text { Patrick S. Ramsey, MD }\end{array}$ \\
\hline $9: 45 \mathrm{am}$ & $\begin{array}{l}\text { The Effect of Intrapartum Group B Streptococcus (GBS) Antibiotic } \\
\text { Prophylaxis on the Prevalence of Non-GBS Neonatal Sepsis } \\
\text { Gary Sutkin, MD }\end{array}$ \\
\hline $10: 00$ am & $\begin{array}{l}\text { Vaginal Defensins are Elevated in Women with Unrecognized } \\
\text { Upper Genital Tract Infection } \\
\text { Harold C. Wiesenfeld, MD, CM }\end{array}$ \\
\hline
\end{tabular}

Break \& Posters (Lakeside A)

Scientific Session IV

\begin{tabular}{|c|l|}
\hline $10: 30$ am & $\begin{array}{l}\text { Evaluation of a Risk Based Strategy to Prevent Neonatal } \\
\text { Infections with Group B Streptococcus } \\
\text { Kevin A. Ault, MD }\end{array}$ \\
\hline $10: 45$ am & $\begin{array}{l}\text { Assessment of Plasma, Vaginal and Cervical HIV-1 Viral Load Throughout } \\
\text { the Menstrual Cycle in HIV Infected Women } \\
\text { Deborah Money, MD, FRCSC }\end{array}$ \\
\hline
\end{tabular}

IDSOG/SmithKline Beecham Fellowship Award Presentation

Charles Allen Black, Ph.D

Magee-Womens Research Institute

"The Role of Allergy in Candida Vaginitis" 
$11: 15 \mathrm{am}$

\begin{tabular}{|c|c|}
\hline 11:30 am - noon & $\begin{array}{l}\text { Introduction: Stanley Gall, MD } \\
\text { HCV in Women, Babies and Providers } \\
\text { Harold Margolis, MD } \\
\text { CDC-P }\end{array}$ \\
\hline
\end{tabular}

12:00 - 1:00 pm IDSOG Business Meeting

6:00 - 9:00 pm Annual Society Banquet; Awards Presentations (Lakeside B/C)
IDSOG/ U.S. Pharmaceuticals, Pfizer Inc. Fellowship Award Presentation Harold C. Wiesenfeld, MD

University of Pittsburgh School of Medicine

Magee-Womens Hospital

"A Randomized Trial of an Intensive Reminder Program to Improve Compliance with

Hepatitis B Vaccination Among Adolescents"

\section{Saturday, August 5, 2000}

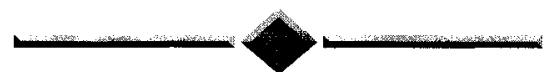

7:00 am - 1:00 pm Registration (Lakeside Lobby A)

General Sessions (Lakeside B)

8:00-9:00 am

Moderator: Stanley Gall, MD

State of the Art: HIV Care in Pregnancy

Heather Watts, MD

Director of Ob/Gyn Research, NIH/NICHD/CRMC/PAMA

Howard Minkoff, MD

Professor, Maimondes Medical Center

9:00-10:15 am

Scientific Session V

\begin{tabular}{|c|l|}
\hline $9: 00 \mathrm{am}$ & $\begin{array}{l}\text { Infection and Inflammation in Perspective: Etiologic Categories } \\
\text { of Preterm Birth in Denver } \\
\text { James McGregor, MD }\end{array}$ \\
\hline $9: 15 \mathrm{am}$ & $\begin{array}{l}\text { Acquisition of Bacterial Vaginosis Among A Longitudinal } \\
\text { Cohort of Non-Pregnant Women } \\
\text { Marijane A. Krohn, Ph.D }\end{array}$ \\
\hline $9: 30 \mathrm{am}$ & $\begin{array}{l}\text { Obstetrical Complications, Maternal/Fetal Toxicities and Vertical } \\
\text { Transmission in Combination Antiretroviral-Treated } \\
\text { Pregnant Women } \\
\text { Deborah Money, MD, FRCSC }\end{array}$ \\
\hline 9:45 am & $\begin{array}{l}\text { The Role of Ethnicity and Vaginal Lactobacilli in Gonorrhea Infection } \\
\text { Sharon L. Hillier, Ph.D }\end{array}$ \\
\hline 10:00 am & $\begin{array}{l}\text { Utility of PCR in The Diagnosis and Management of Normal PH, KOH } \\
\text { and Culture-Negative Candida Vaginitis. } \\
\text { A Longitudinal Study in 27 Patients } \\
\text { Jack D. Sobel, MD }\end{array}$ \\
\hline
\end{tabular}

$10: 15-10: 30 \mathrm{am}$

Break \& Posters (Lakeside A)

196 - INFECTIOUS DISEASES IN OBSTETRIGS AND GYNECOLOGY 


\begin{tabular}{|c|l|}
\hline 10:30 am & $\begin{array}{l}\text { Invasion of HeLa Epithelial Cells by Group B Streptococcus Isolates from } \\
\text { Neonatal Blood and the Maternal Genital Tract } \\
\text { Gregory Locksmith, MD }\end{array}$ \\
\hline 10:45 am & $\begin{array}{l}\text { The Effect of Highly Active Antiretroviral Therapy (HAART) on CIN in } \\
\text { HIV Infected Women: A Case-Control Study } \\
\text { Rajiv Shah, MD }\end{array}$ \\
\hline 11:00 am & $\begin{array}{l}\text { Pattern of Gestational Pyelonephritis in the Age of Antibiotic Resistance } \\
\text { Tony Wen, MD }\end{array}$ \\
\hline
\end{tabular}

$11: 15 \mathrm{am}-12: 30 \mathrm{pm}$

IDSOG Task Teams Reports

$12: 30 \mathrm{pm}$

Closing Remarks: Stanley Gall, MD 

Thursday, August 3, 2000

General Sessions

Scientific Session I

9:00 - 10:15 AM

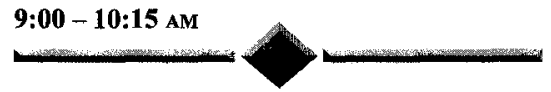

Best Abstract Award

THE EFFECT OF HUMAN NEUTROPHIL PEPTIDES (DEFENSINS) ON CYCLOOXYGENASE-2 EXPRESSION AND PROSTAGLANDIN PRODUCTION IN HUMAN AMNION CELLS

PN Rauk and JP Chiao Magee-Womens Research Institute and the Department of Obstetrics, Gynecology, and Reproductive Sciences, Univ. of Pittsburgh School of Medicine, Pittsburgh, PA

Objective: Human neutrophil peptides (HNP 1-3, Defensins) are small peptides found in large concentrations in neutrophil granules and are released in the initial response to infection. Defensin concentrations are 4-24 times higher in amniotic fluid in women with preterm labor and intraamniotic infection than in uninfected controls. ${ }^{1}$ The contribution of defensins to preterm labor is unknown. Because defensins integrate into cell membranes and induce nuclear translocation of nuclear factor kappa $B$, we hypothesized that they would induce the expression of the inducible form of cyclooxygenase, COX -2 and increase prostaglandin production in amnion cells. The purpose of this study was to measure the effect of defensins on COX2 gene and protein regulation and on prostaglandin production in cultured human amnion cells.

Study Design: Amnion was obtained from placentas of women undergoing elective cesarean section at term. Individual amnion cells were isolated after enzymatic digestion. Cells were grown to confluence on culture plates, serum-starved for 24 hours, and treated with human neutrophil peptide-1 (HNP-1), $25 \mathrm{~g} / \mathrm{ml}$, for 24 hours. Total RNA and protein were isolated at various times and COX-2 mRNA expression was measured by RT-PCR and COX-2 protein was measured by western blot. Supernatants were collected, and PGE2 concentration was measured using radioimmunoassay.

Results: HNP-1 treatment resulted in a rapid increase in COX-2 mRNA expression beginning after 2 hours and reached a maximum 5 -fold increase by 4 hours of treatment. Cyclooxygenase- 2 protein was similarly increased beginning at 4 hours and reaching a maximum increase of 5 -fold at 24 hours of treatment. Prostaglandin production by amnion cells increased approximately 5-fold after exposure to HNP-1 for 24 hours.

Conclusions: Human neutrophil peptides (defensins) induce COX2 gene and protein expression and prostaglandin synthesis in cultured human amnion cells. Defensins, in addition to cytokines, may provide another mechanism through which the host immune response contributes to prostaglandin-mediated preterm parturition. (Supported by March of Dimes 6-FY99-398)

'Heine RP, Wiesenfeld H, Mortimer L, Greig PC. Amniotic fluid defensins: potential markers of subclinical intrauterine infection. Clin Infect Dis 1998:27;513-518.

HYDROGEN PEROXIDE-PRODUCING VAGINAL LACTOBACILLI SUPPRESS HIV-1 EXPRESSION IN VITRO

D Landers, G Duarte, L Cosentino, MAntonio, P Gupta, S Hillier, University of Pittsburgh and Magee-Womens Research Institute, Pittsburgh, PA
Objectives: Epidemiological studies have linked bacterial vaginosis (BV) with HIV-1 seroconversion. A lack of hydrogen peroxide $\left(\mathrm{H}_{2} \mathrm{O}_{2}\right)$-producing vaginal lactobacilli is a key feaure of BV. A suppository using Lactobacillus crispatus strain LC 2116 is under development to protect against recurrence of BV. Both $\mathrm{H}_{2} \mathrm{O}_{2}$-producing and $\mathrm{H}_{2} \mathrm{O}_{2}$-negative strains of Lactobacillus crispatus and another Lactobacillus species were studied for effects on HIV-1 replication in $\mathrm{U} 1$ cells in vitro.

Study Design: Chronically HIV-1 infected monocytic cells (U1 cells) were coincubated with $107 \mathrm{CFU}$ of Lactobacillus species. HIV-1 replication was determined by $\mathrm{p} 24$ antigen measurements at 24,48 , 72 , and 96 hrs.

Results: HIV replication was markedly suppressed when exposed to $\mathrm{H}_{2} \mathrm{O}_{2}$-producing Lactobacillus but not $\mathrm{H}_{2} \mathrm{O}_{2}$-negative Lactobacillus crispatus. Suppression was the greatest when exposed to the LC 2116 reaching 22 fold by $96 \mathrm{hr}$. No change in pH occurred during incubation.

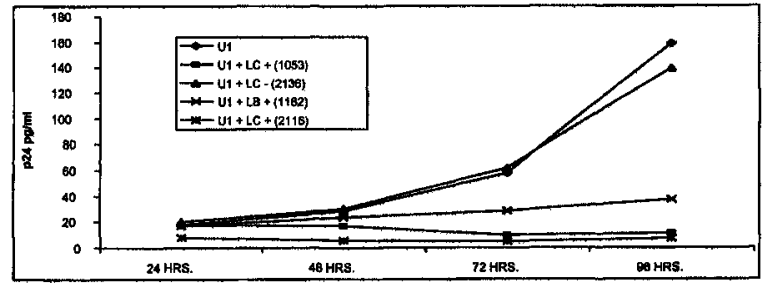

Conclusion; In vitro, $\mathrm{H}_{2} \mathrm{O}_{2}$-producing Lactobacillus crispatus suppresses HIV replication. This effect is also seen with another $\mathrm{H}_{2} \mathrm{O}_{2}$ producing Lactobacillus but not $\mathrm{H}_{2} \mathrm{O}_{2}$-negative Lactobacillus crispatus. The effect is independent of $\mathrm{pH}$.

\section{Best Young Investigator Award PERIDONTAL DISEASE AND SPONTANEOUS PRETERM BIRTH}

KA Boggess, S Lieff, AP Murtha, K Moss, J Beck, and S Offenbacher University of North Carolina at Chapel Hill Center for Oral and Systemic Diseases Chapel Hill, NC

Objective: Periodontal disease, a chronic gram-negative infection that induces both local and systemic inflammation has been associated with several adverse health outcomes. Our objective was to determine the relationship between periodontal disease and spontaneous preterm birth.

Study Design: A prospective cohort study of pregnant women were enrolled at $<26$-week gestation and followed until delivery. Maternal demographic and medical information was chart abstracted. Periodontal examinations were performed at enrollment and after delivery, with periodontal disease specified as 4 or more sites with gingival pockets $>5 \mathrm{~mm}$ in depth. Spontaneous preterm birth (SPTB) was defined as preterm delivery $<37$ or $<34$ weeks as a result of preterm labor or premature rupture of membranes. Medically indicated preterm births were excluded. Univariate and logistic regression analysis adjusting for periodontal disease at enrollment or progression during pregnancy, maternal age, race, prior preterm birth, treatment for $\mathrm{BV}$, and tobacco use was used to determine the relative risk of SPTB.

Results: Seven hundred thirty-three women have been enrolled, with complete data available on 243 . The incidence of periodontal dis- 
ease at enrollment was $17.6 \%$, and $52.0 \%$ of women had progression of their periodontal disease during the course of pregnancy. Seventy ( $28.8 \%$ ) of 243 delivered $<37$ weeks; $25(10.2 \%)$ of 243 women delivered at $<34$ weeks. Compared to no periodontal disease and no progression, the relative risk and 95\% confidence interval for SPTB, from the logistic regression model, were as follows:

\begin{tabular}{lll}
\hline Periodontal disease & For SPTB $<37$ weeks & For SPTB $<34$ weeks \\
\hline At enrollment & $3.3(1.6-6.7)$ & $3.0(1.0-8.9)$ \\
Progression & $1.6(0.9-2.8)$ & $2.0(0.8-5.1)$ \\
\hline
\end{tabular}

Conclusions: Periodontal disease is associated with spontaneous preterm birth at $<37$ weeks, even after controlling for other risk factors. Small sample size limits conclusions regarding SPTB at $<34$ weeks. Whether this association is due to maternal or fetal inflammatory responses as a consequence of oral infection or represents a marker for other host factors that predispose to spontaneous preterm birth remains to be studied.

Supported by NIDCR grant RO-1-DE-12453, P-60-DE-13079 and T32-DE-07310.

ADMINISTRATION OF PNEUMOCOCCAL POLYSACCHA-
RIDE VACCINE (PNCP)AND THE PURIFIED FUSION PRO-
TEIN (PFP-2) FOR RESPIRATORY SYNCYTIAL VIRUS TO
PREGNANT WOMEN
WP Glezen, FM Munoz, PA Piedra, ML Maccato, PM Pinell. Baylor WP Glezen, FM Munoz, PA Piedra,
College of Medicine, Houston, TX

Objective: To determine the safety and immunogenicity of vaccines when administered during the third trimester of pregnancy. Study Design: After informed consent, women early in the third trimester were randomly assigned to receive $\mathrm{PncP}$ or a comparison vaccine in one trial and PFP-2 or placebo in a second trial. The women and their offspring were followed closely for adverse effects. Serum and breast milk specimens were obtained to measure specific antibodies and these studies are in progess.

Results: 20 women received either PncP or PFP-2 in these trials. The vaccines were well tolerated and no serious adverse effects related to the vaccines were observed. All women delivered healthy infants $>2$ weeks following vaccination. Women who received PncP had significantly higher $\operatorname{IgA}$ antibody levels to pneumococcal types $6 \mathrm{~B}, 14,19 \mathrm{~F}$ and $23 \mathrm{~F}$ in breast milk. A trend was seen for less frequent acquisition of pneumococcal nasal carriage by their infants. Infants whose mothers received PFP-2 vaccine had fewer respiratory illnesses during the RSV season than infants of placebo recipients. Further studies are in progress.

Conclusions: The vaccines were benign in effects when administered in the third trimester. The presence of increased IgA antibodies in breast milk of immunized women suggests enhanced mucosal immunity and may be a factor in reducing risk of carriage for their infants. PFP-2 vaccine looks promising and is being considered for larger phase II trials to determine safety and immunogenicity.

\section{AMNIOTIC FLUID LIPOPOLYSACCHARIDE BINDING PROTEIN AND SOLUBLE CD14 AS MEDIATORS OF THE INFLAMMATORY RESPONSE IN PRETERM LABOR}

Carolyn Gardella, Jane Hitti, Thomas R. Martin, David A. Eschenbach, Departments of Obstetrics and Gynecology and Medicine, University of Washington, Seattle, WA

Objective: To determine the presence of lipopolysaccharide binding protein (LBP) and soluble CD14 (sCD14) in the pro-inflammatory response among women in preterm labor.
Study Design: A cohort of 169 afebrile women in preterm labor with intact membranes had amniotic fluid (AF) collected by transabdominal amniocentesis for culture and for LBP, sCD14 and interleukin- 6 (IL-6) determinations by ELISA. IL-6 levels of $>2000 \mathrm{pg} / \mathrm{ml}$ were considered positive. Statistical analyses included ANOVA, multiple comparisons with Bonferroni correction, and linear regression.

Results: All 169 samples had measurable LBP and sCD14 present. Subjects were categorized by AF culture and IL-6 results. Geometric mean LBP and sCD14 levels differed significantly among groups:

\begin{tabular}{|c|c|c|c|c|}
\hline & $\begin{array}{c}(-) \text { Culture/ } \\
(n=17)\end{array}$ & $\begin{array}{c}(-) \text { Culture/ } \\
(+) 1 \mathrm{~L}-6 \\
(\mathrm{n}=20) \\
\end{array}$ & $\begin{array}{c}(-) \text { Culture/ } \\
(-) \Pi L-6 \\
(\mathrm{n}=132) \\
\end{array}$ & $P^{*}$ \\
\hline LBP $\mathrm{ng} / \mathrm{ml} / \mathrm{mg}$ protein & 113.76 & 122.74 & 52.36 & $<0.001$ \\
\hline $\mathrm{sCD} 14 \mathrm{ng} / \mathrm{ml} / \mathrm{mg}$ protein & 99.08 & 105.68 & 42.95 & $<0.001$ \\
\hline
\end{tabular}

*One-way ANOVA

Independent of AF culture and IL-6, SCD14 was associated with enrollment gestational age (GA). Among culture negative, IL-6 negative subjects, GA was inversely associated with $\mathrm{SCD} 14$ levels such that sCD14 decreased $9.4 \%$ for each additional week gestation (95\% CI: $7.1-11.7 \%, \mathrm{P}<0.001$ ). LBP levels showed a similar trend $(\mathrm{P}=0.09)$

Multivariable linear regression with adjustment for GA showed that IL-6 increased by $131 \%$ for every ten-fold increase in LBP $(95 \% \mathrm{CI}$ : $30-311 \%, \mathrm{P}=0.005)$ and by $3,311 \%$ for every 10 -fold increase in sCD14 (95\%CI: 1,268-8,411\%, P<0.001).

Conclusions: LBP and SCD14 may mediate the production of IL-6 among women in preterm labor. These molecules may also explain the activation and amplification of the cytokine cascade in the absence of culturable quantities of microbes. Further study of the effect of GA on these inflammatory mediators is warranted.

PRENATAL DIAGNOSIS OF CONGENITAL CMV INFECTION: VALIDATION OF LOW-LEVEL COPY COUNTS OF CMV-DNA IN AMNIOTIC FLUID ANALYZED BY QUANTITATIVE PCR

N Silverman; D Lehman; M Toyoda; D Carlson; L Platt, S Jordan. Divisions of Maternal-Fetal Medicine, Pediatric Infectious Diseases, Reproductive Genetics, and Transplant Immunology, Cedars-Sinai Medical Center, Burns and Allen Research Institute, Los Angeles, CA

Objective: Cytomegalovirus (CMV) remains the most common congenital viral infection. DNA-based analysis of amniotic fluid (AF) from at-risk pregnancies has been suggested as an adjunct to or substitute for culture. However, little information exists to establish appropriate cutoffs between "negative" and "positive" results for quantitative tests on AF. We sought to validate criteria for diagnosing congenital CMV infection by quantitative PCR of AF, using culture results and neonatal outcomes for comparison.

Study Design: AF samples sent for CMV evaluation from a single prenatal diagnostic center to the inhouse microbiology lab for a standard shell-culture assay and to the inhouse transplant immunology lab for quantitative CMV-PCR assay were retrospectively evaluated.. The sensitivity of the quantitative CMV-DNA PCR assay is 1 copy/ g DNA. All PCR assays were run in duplicate with results averaged.

Results: From 11/97 to $12 / 99$, 75 women underwent prenatal diagnosis for suspicion of congenital CMV infection. Of these, $95 \%$ had ultrasound findings (U/S), most commonly echogenic fetal bowel $(69 \%)$. CMV copy counts $=0$ were found in $37(49.3 \%)$ samples; all AF samples in this group also had negative CMV cultures, and all neonates were unaffected by CMV. Three women (4\%) hadAF CMV 
copy counts > 10; all had U/S findings and $2 / 3$ had (+) CMV cultures.All 3 terminated their pregnancies. The other 35 women $(46.7 \%)$ were in the "low-level copy count" group, with PCR results on AF $>$ 0 and $<10$ (median $=0.9$, range $0.1-6 ; 34 / 35$ were $<5$ ). No patient in this group had a $(+) \mathrm{CMV}$ culture and no infected newborns have been diagnosed to date.

Conclusions: This study is the largest to validate quantitative CMVDNA analysis of AF by PCR as a useful diagnostic test for congenital CMV infection. Copy counts $<5$ (and possibly $<10$ ) are associated with negative CMV culture results and non-CMV-infected newborns. A prospective surveillance study in low-risk pregnancies using quantitative PCR is planned.

Thursday, August 3, 2000

General Sessions

Scientific Sessions II

10:45 - 12:00

MOLECULAR CHARACTERIZATION OF RECURRENT VULVOVAGINAL CANDIDIASIS: A COMPARISON OF ELECTROPHORETIC KARYOTYPING AND RANDOMLY AMPLIFIED DNA FINGERPRINTING

JA Hidalgo, JA Vazquez, RAAkins, JD Sobel, Division of Infectious Diseases, Detroit Medical Center/Wayne State University School of Medicine, Detroit, MI

Objective: The molecular delineation of Candida albicans (CA) infecting patients with recurrent vulvovaginal candidiasis (RVVC) has been studied by pulsed-gel electrophoresis and show stability of the molecular configuration of the infecting strains with minor changes over time. Randomly amplified polymorphic DNA fingerprinting (RAPD) has not been previously utilized in this situation. In this study we compared both techniques to evaluate further the molecular epidemiology of RVVC.

Study Design: We analyzed $74 \mathrm{CA}$ isolates recovered from 10 women with RVVC and an average follow up of 60.8 months (range 6-105 mo.). Each patient had a minimum of 5 positive cultures. Electrophoretic karyotyping (CHEF) and RAPD DNA fingerprinting using different two different primers were utilized to delineate the CA strains. Results: All isolates were identified as CA using germ tube formation and standard biochemical testing. In 7 of 10 women, only 1 strain type was identified with CHEF throughout follow-up. In 2 women, 2 different strains were identified over a 46-78 month follow-up, and one had 3 strains over a 105 month follow-up. Using the RAPD method and 2 primers we were able to demonstrate that the majority of women $(6 / 10)$ maintained $1-2$ strains throughout the entire follow-up. However, $80 \%$ of patients also had "substrains" of the primary clone during the follow up period. These substrains demonstrated minor genetic alterations in serial infections.

Conclusion: The results confirm the large diversity of strain types of $\mathrm{CA}$ and demonstrate the persistence of primary strains in individual patients and 1-3 substrains over prolonged periods of time. These results also support the concept that RVVC is due to vaginal relapse or endogenous reinfection with the same strain of $\mathrm{CA}$.

\section{VAGINAL NONOXYNOL-9 (N-9) SPERMICIDE USE WITH INTERCOURSE}

Dorothy Patton, David Eschenbach, Jan Aura, Amalia Meier. Department of Obstetrics and Gynecology, University of Washington, Seattle, WA
Background: N-9 is a nonionic detergent spermicide that has been associated with genital ulcers at a $1000 \mathrm{mg}$ dose. N-9 use without intercourse caused a decrease in the incidence of Lactobacillus and an increase in $E$. coli.

Objectives: To assess the effects on the vaginal ecosystem and tissues of a twice daily for 3 days application of a $100 \mathrm{mg}$ insert of $\mathrm{N}$ 9 (Ortho Options Conceptrol Inserts) with vaginal intercourse two times in the 3 days.

Study Design: Nineteen women received the $100 \mathrm{mg}$ N-9 regimen before intercourse (IC) using nonspermicidal condoms. Prior to and after $\mathrm{N}-9$ application, the vaginal epithelium was examined grossly, colposcopically, histologically, and vaginal flora was assessed. Similar evaluations occurred after IC with the N-9 product (see below). Results:

\begin{tabular}{|c|c|c|c|c|c|}
\hline & $\begin{array}{l}\text { Day I } \\
\text { Prior to } \\
\text { N-9 }\end{array}$ & $\begin{array}{l}8-12 \mathrm{hrs} \\
\text { After IC } \\
\text { w/N-9 }\end{array}$ & $\begin{array}{c}3-4 \text { days } \\
\text { After IC } \\
\text { w/N-9 }\end{array}$ & $\begin{array}{l}\text { 6-8 days } \\
\text { After IC } \\
\text { w/N-9 }\end{array}$ & $\begin{array}{l}\text { Test } \\
1 / 2^{*}\end{array}$ \\
\hline \multicolumn{6}{|l|}{ Colposcopic exam } \\
\hline Vaginal erythema & 0 & $11(58 \%)$ & $1(5 \%)$ & $2 / 14(14 \%)$ & $<0.006 / 0.2$ \\
\hline Vaginal $\mathrm{pH}>4.7$ & $1(5 \%)$ & $17(89 \%)$ & $12(63 \%)$ & $5 / 13(38 \%)$ & $<0.0001 / 0.02$ \\
\hline Vaginal clue cells & 0 & $9(47 \%)$ & $8(42 \%)$ & $1 / 17(6 \%)$ & $0.004 / 0.9$ \\
\hline Vaginal neutrophils $>1$ & $11 / 18(61 \%)$ & $8 / 18(44 \%)$ & $13 / 18(72 \%)$ & $15 / 18(83)$ & $0.2 / 0.07$ \\
\hline Mean neutrophils & $1.90 .3 * *$ & 2.10 .3 & 1.60 .2 & $2.3 \quad 0.3$ & $0.5 / 0.6$ \\
\hline Cervical neutrophils $>11$ & $5 / 18(28 \%)$ & $14 / 17(82 \%)$ & $9 / 17(53 \%)$ & $9 / 18(50 \%)$ & $0.007 / 0.8$ \\
\hline Log E. coli & 6.0 & 6.6 & 6.0 & 3.8 & $0.08 / 0.5$ \\
\hline $\begin{array}{l}\text { Log total } \\
\text { Lactohacillus }\end{array}$ & 8.0 & 5.3 & 8.0 & 8.0 & $0.001 / 0.7$ \\
\hline $\begin{array}{l}\text { Log total non- } \\
\text { Lactobacillus sp. }\end{array}$ & 7.0 & 7.9 & 8.3 & 7.0 & $0.05 / 0.9$ \\
\hline
\end{tabular}

*Using logistic regression for correlated data, Test 1 compares visit 3 with visits 1 and 2 and Test 2 determines a linear trend for visits $3-5$.

***Biopsy was performed one month prior.

The multiple use of $100 \mathrm{mg}$ of $\mathrm{N}-9$ with intercourse was associated with vaginal erythema, elevation in $\mathrm{pH}$ and cervical neutrophils, increase in non-Lactobacillus sp. and decrease in Lactobacillus concentration. Subepithelial neutrophils appear unchanged.

Conclusions: The $100 \mathrm{mg} \mathrm{N}-9$ dose transiently disturbs vaginal $\mathrm{pH}$ and flora with recovery within a week.

Supported by R01 HD33203 from the National Institutes of Health.

\section{EFFECT OF VAGINAL DOUCHING ON VAGINAL PHYSI- OLOGY}

David A. Eschenbach, Dorothy Patton, Jan Aura, Soe Soe Thwin Department of Obstetrics and Gynecology, University of Washington, Seattle, WA

Objectives: To assess the effects of vaginal douching over a one month period on vaginal epithelium and microflora.

Study Design: Thirty volunteer women were randomly assigned to one of four commercial douching products that contained octoxynol9, betadine, baking soda, or vinegar. Assessment of the vaginal epithelium was made by gross, colposcopic, and histologic examination and vaginal flora was cultured. A comparison was made of the findings at baseline (day 1 prior to), and after douching once, five times over a month period and 8 days later, using logistic regression for correlated data.

Results:

\begin{tabular}{|c|c|c|c|c|c|}
\hline & Baseline & $\begin{array}{l}\text { After } \\
\text { I time }\end{array}$ & $\begin{array}{c}\Lambda \mathrm{fter} \\
5 \text { times }\end{array}$ & $\begin{array}{l}\text { 8days } \\
\text { later }\end{array}$ & $P$-value \\
\hline Total Lactobacillus & 22 & 23 & 24 & 25 & 0.4 \\
\hline Enterococcus & 12 & 13 & 16 & 8 & $<0.01$ \\
\hline BV Score 4 & 3 & 4 & 8 & 7 & 0.01 \\
\hline Cervical $\mathrm{WBC}>10$ & 3 & 18 & 22 & 16 & 0.02 \\
\hline $\begin{array}{l}\text { Octoxynol-9 product } \\
\text { only subepithelial } \\
\text { WBC }\end{array}$ & $2.1 \quad 0.3$ & $\begin{array}{ll}1.7 & 0.3\end{array}$ & $4.3 \quad 0.8$ & $1.5 \quad 0.4$ & $0.02^{1}<0.001^{*}$ \\
\hline
\end{tabular}

+ Test compares difference between baseline and after 5 times of douching.

* Test compares difference after 5 times of douching and 8 days later. 
There was no significant change in other vaginal flora or in the gross or colposcopic appearance of the epithelium for any product. Subepithelial WBC did not change among subjects using products other than octoxynol-9.

Conclusion: Douching 5 times a month produces a transient increase in Enterococcus and the vaginal Gram stain. Cervical WBC also increased, and for users of octoxynol-9, an increase occurred in subepithelial WBC. Recovery was evident 8 days later.

Supported by R01 HD33203 from the National Institutes of Health.

\section{BETA DEFENSIN-1 IS VARIABLY EXPRESSED IN CELLS OF HUMAN AMNIOCHORION}

Deborah Draper, Erika Valore, Tomas Ganz, and.R. Phillip Heine. Magee-Women's Research Institute and Dept. Obstetrics, Gynecology and Reproductive Sciences, University of Pittsburgh, Pittsburgh, PA and University of California, Los Angeles, Dept of Medicine, Los Angeles, CA

Human beta defensins (HBD-1 and 2) are antimicrobial peptides produced by mucosal epithelial cells in host defense settings. HBD-1 is thought to be expressed constitutively while HBD-2 expression is inducible by inflammatory stimuli. Beta defensins have not been described in human gestational tissues.

Objectives: To determine the expression of HBD-1 in cells of fetal membranes from normal term $(n=6)$ and preterm deliveries $(n=15)$ including preterm labor (PTL), premature rupture of membranes (pPROM), and preeclampsia (PE).

Study design: Tissues $(n=21)$ were collected immediately after delivery and fixed for immunohistochemical staining for HBD-1 with rabbit specific antiserum, and flash frozen for biochemical analysis. The paraffin embedded tissues were sectioned and adjacent sections were tested with HBD-1 antiserum or control (prebleed) antiserum. Two independent investigators, unaware of the delivery information, read the immunostained slides, with subsequent clinical correlation. Results: HBD-1 was expressed in cells of the amnion, chorion, and decidua.Amnion epithelium was most frequently positive and stained in 6 of 10 pPROM; 1 of 5 in PE and PTL; 3 of 6 normal, term deliveries. It was found in highest concentration in trophoblast cells of chorion and variably expressed in adjacent amnion epithelial cells within a membrane. There was variation from patient to patient in the type of cells positive for HBD-1 and the intensity of staining, which may reflect variable responses to unknown signals. There was no correlation of HBD-1 expression with labor or gestational age. Conclusions: HBD-1 was found in trophoblast cells, amnion epithelium, and decidual cells and was differentially expressed in amnion cells within the same membrane. Thus, several cell types are capable of producing defensive molecules in human gestational tissues. Variations in staining of HBD-1 in human gestational tissues suggest that the synthesis of this peptide is responsive to as yet unknown local stimuli.

\section{ANTIMICROBIAL PROTEIN PRODUCED BY VAGINAL LACTOBACILLUS SPECIES, RECOVERY AND PURIFICA- TION}

Alla Aroutcheva, Jose A. Simoes, Sebastian Faro. Rush-Presbyterian-St. Luke's Medical Center, Chicago, IL; State University of Campinas (Unicamp), Brazil

Objectives. The purpose of this study was to investigate the ability of Lactobacillus species to produce bacteriocin, and to develop a method for isolation and purification of that antibacterial protein. Study Design. Thirty-five different strains of vaginal Lactobacillus species were screened for inhibition effect versus Gardnerella vaginalis, Prevotella bivia, Peptostreptococcus anaerobius, Escherichia coli, and group B Streptococcus using multilayer agar method. One of the high producers of bacteriocin, L. acidophilus 160 , was chosen for protein extraction. After overnight growth in MRS broth cells were removed with centrifugation, washed, and transferred into $200 \mathrm{ml}$ of defined media ( $\mathrm{pH} \mathrm{6.0)}$ designed biochemically close to vaginal fluid, but without proteins. After $18 \mathrm{hrs}$ of anaerobic incubation with constant shaking, cells were removed with centrifugation, and crude supernatant was tested for $\mathrm{pH}$, protein concentration (BCA method), bioassay versus $G$. vaginalis, and SDS-PAGE electrophoresis. Protein was extracted with $80 \%$ of ammonium sulfate; pellet and supernatant dialyzed, concentrated, and tested for activity.

Results. Of the tested Lactobacillus isolates, $80.2 \%$ possessed bacteriocin activity and inhibited growth of all tested microflora. Crude supernatant of defined media obtained after $18 \mathrm{hrs}$ of growth had a

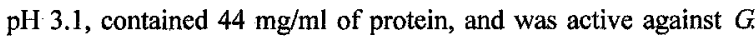
vaginalis. Six bands from 6 to $60 \mathrm{kDa}$ appeared in the gel. After ammonium sulfate precipitation fraction, pellet, and supernatant had a $\mathrm{pH}$ 7.0. Active protein against $G$. vaginalis was captured in supernatant, and apparently was not precipitated by $80 \%$ ammonium sulfate. According to gel electrophoresis, the size of that protein was in range, 6-7 kDa.

Conclusion. Most vaginal Lactobacillus species produce antibacterial protein that is able to inhibit growth of other vaginal pathogens. Applied method for protein purification is simple, and allowed to recover the protein in a short period of time.

Friday, August 4, 2000

General Sessions

Scientific Sessions III

9:00 - 10:15 AM

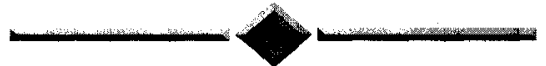

\section{CROMOLYN CREAM FOR RECALCITRANT IDIOPATHIC VULVAR VESTIBULITIS: RESULTS OF A PLACEBO-CON- TROLLED STUDY}

P Nyirjesy, JD Sobel, MV Weitz, DJ Leaman, MJ Small, SP Gelone. Temple University School of Medicine, Philadelphia, PA, and Wayne State University School of Medicine, Detroit, MI

Objective. Patients with chronic idiopathic vulvar vestibulitis syndrome (VVS) have increased mast cells when biopsied, and topical cromolyn has been suggested as a treatment. The purpose of this study was to assess the efficacy of $4 \%$ cromolyn cream in women with VVS.

Study design. A prospective, two-center, double-blind, randomized, placebo-controlled was initiated at two centers. Patients with VVS were assigned to apply cromolyn or placebo cream to the vestibule. Symptoms (burning, irritation) and signs (erythema, extent of erythema, tenderness) were each recorded on a $0-3$ scale. In the sexually active patient subgroup, dyspareunia was also evaluated.

Results. Thirteen of the 26 evaluable patients received cromolyn. Patients in the cromolyn arm were more likely to have failed therapy with amitriptyline $(P=0.05)$, but the two groups were otherwise similar upon study entry. Overall, scores decreased from a median of 9 to $5(P=0.001)$, but the level of improvement was similar between treatment and placebo groups. Improvement was unrelated to duration of symptoms, fluconazole use, or sexual activity. Five (38.5\%) cromolyn and one $(7.7 \%)$ placebo patients rated their symp- 
tom improvement at $70 \%$ or greater reduction in symptoms $(P=$ 0.16 ). In the 21 sexually active patients, the total score decreased from a median of 12 to $8(P=0.005)$, but there was no statistically significant difference between study arms.

Conclusions. Cromolyn cream did not confer a significant benefit in patients with vulvar vestibulitis. The large placebo response suggests the need for large well-controlled studies of other treatment modalities.

\section{PATIENTS' AND PHYSICIANS' ACCEPTANCE OF INFLU- ENZA VACCINE IN PREGNANCY}

NN. Silverman; A. Greif, Division of MFM, Cedars-Sinai Medical Center, Los Angeles, CA

Objective: Despite the availability of vaccine to prevent illness, influenza remains a major source of morbidity during outbreak seasons, particularly among pregnant women and newborns under 6 months. Evidence exists that maternal immunization also confers passive immunity for the newborn. We sought to describe and contrast patients' and physicians' attitudes toward influenza vaccination during pregnancy.

Study Design: A 17-item questionnaire was distributed to all women on our postpartum floor from mid-January through March 2000. All surveys were designed to be completed and returned anonymously before patient discharge. A similar 12-item anonymous questionnaire was distributed during the same time period to all obstetricians at our center, along with members of the county ob-gyn society, who faxed their surveys to a central office. Epi-Info 6 was used to tabulate responses and to analyze relations between them.

Results: Responses to date have been analyzed from 198 women (40\% response) and 118 physicians (27.5\% response). Among patients, $32 \%$ had ever had a flu vaccine, $27 \%$ reported flu during the current pregnancy, and $42 \%$ said someone at home was ill with the flu. Only $23 \%$ reported discussing a flu shot with a physician during their pregnancy, with $7.3 \%$ being immunized. Chronic medical conditions (lung disease, smoking, diabetes) were reported by $16 \%$ of patients; they were not more likely to have been vaccinated $(14 \%$ vs $6 \% ; P=0.13$ ), though they were twice more likely to have discussed vaccination with a doctor $(43 \%$ vs $19.5 \%$; $R R=2.2[1.3-$ $3.8] ; P=0.014)$. Prior vaccines against other diseases were reported by $50 \%$ of women, including HBV (30\%) and varicella (36\%); this was not associated with a higher likelihood of influenza vaccination, however. $63 \%$ of women thought that pregnancy had a higher risk of flu complications, though they were not more likely to accept vaccine. More women said they would accept a flu shot if they thought it would protect the newborn (84\%) than if it was simply recommended by their doctor $(53 \%) ; P<0.001$. Among physicians, $45 \%$ reported fielding patients' questions about flu shots either daily or weekly, with $74 \%$ stating they recommended vaccine during pregnancy. Doctors were more likely to recommend flu vaccine to their patients if: they had received a flu shot themselves this season $(91 \%$ vs $49 \%$; $R R=1.9[1.4-2.5]$ ), if they knew the current recommendations for vaccination $(80 \%$ vs $31 \% ; R R=2.6[1.1-5.9])$, and if they believed the vaccine was protective for the newborn ( $84 \% \mathrm{vs}$ $66 \% ; \mathrm{RR}=1.3[1.03-1.6])$.

Conclusions: Pregnant women in this study cohort reported low rates of discussing flu vaccine, despite doctors' reporting a high rate of discussing vaccine with them. Educational focuses to improve vaccination in this target population should include potential benefits for the newborn in addition to maternal benefits. A "disconnect" may exist between physicians' educational efforts and actual patient understanding of flu vaccine during pregnancy, especially since patients report fairly high rates of acceptance of other vaccines.

\section{PHARMACOKINETICS OF AZITHROMYCIN IN THE TERM GRAVIDA}

Patrick S. Ramsey, Megan B. Vaules, Gurinder Vasdev, William W. Andrews, Kirk D. Ramin. Department of Obstetrics/Gynecology and Anesthesia, University of Alabama at Birmingham, Birmingham, AL and Mayo Medical Center, Rochester, MN

Objective: To characterize the pharmacokinetics of azithromycin in the term gravida.

Study Design: Twenty-one women scheduled for elective cesarean delivery were prospectively enrolled and received $1 \mathrm{~g}$ of azithromycin at either $6,12,24,72$, or 168 hours preoperatively. All women received spinal anesthesia at which time a sample of cerebrospinal fluid was obtained for analysis. Maternal serum and urine were obtained immediately prior to surgery. Intraoperatively, samples of myometrium, adipose tissue, placenta, amniotic fluid, and umbilical arterial and venous cord blood were obtained.Azithromycin levels were quantitatively determined using a high-pressure liquid chromatography with electrochemical detection.

Results: All patients tolerated the preoperative azithromycin without significant adverse reactions. While peak maternal serum azithromycin levels were reached within 6 hours of drug administration, short serum half-life resulted in a rapid decline in drug concentration over the initial 24 hours following drug administration $(6 \mathrm{hr}-$ $311 \mathrm{ng} / \mathrm{mL}, 24 \mathrm{hr}-63 \mathrm{ng} / \mathrm{mL}$ ). In contrast, azithromycin in myometrial, adipose, and placental tissue had significantly longer half-life, with higher and sustained drug levels (>500 ng/mL) noted up to 72 hr. High urine levels of azithromycin $(>5000 \mathrm{ng} / \mathrm{mL}$ ) were similarly noted during the initial 72 hours following drug administration. Umbilical arterial and venous serum azithromycin levels were low (19-38 ng/mL) during the first 72 hours. Amniotic fluid levels were highest at 6 hours $(151 \mathrm{ng} / \mathrm{mL})$ and declined rapidly. Maternal cerebrospinal azithromycin concentrations were undetectable for all timepoints.

Conclusions: Azithromycin has a rapid serum half-life in the term gravida, with prolonged drug half-life and high, sustained levels of drug noted within myometrium, adipose, and placental tissue. Low fetal azithromycin levels are present in umbilical cord blood and amniotic fluid. Given the broad antimicrobial spectrum and placental penetration, azithromycin may have potential use for the treatment of perinatal infections.

THE EFFECT OF INTRAPARTUM GROUP B STREPTOCOCCUS (GBS) ANTIBIOTIC PROPHYLAXIS ON THE PREVALENCE OF NON-GBS NEONATAL SEPSIS

G Sutkin, RL Sweet; RP Heine. Magee-Womens Research Institute and Department of Obstetrics, Gynecology and Reproductive Sciences, University of Pittsburgh, Pittsburgh, PA

Objectives: Group B streptococcus (Streptococcus agalactiae, GBS) represents the most common cause of neonatal bacterial sepsis and meningitis among newborns in the United States. In 1996, the Center for Disease Control issued guidelines for GBS antibiotic prophylaxis during labor. Our institution opted to offer prophylaxis to all GBS carriers identified at 35-37 weeks and to those with risk factors prior to 37 weeks. A recent analysis (Brozanski, OBGYN, 95:496) showed an 87\% reduction in neonatal GBS sepsis after the institution of this policy; however, it is unclear what effect widespread antibiotic use in labor has on other types of bacteria. The purpose of this study was to determine if the change in antibiotic prophylaxis at our institution changed the incidence of non-GBS neonatal sepsis.

Study Design: Microbiology cultures originating from our neonatal intensive care unit from 1992 through 1999 were re- 
viewed. Maternally-acquired neonatal sepsis was defined as a positive blood or tissue culture within the first 48 hours of neonatal life. Prevalence of non-GBS neonatal sepsis in the study period (October 1, 1995 through August 31, 1999) was compared with that in the control period (January 1, 1992 through June 30,1995). Chi-square tests were used to determine statistical significance.

Results: The prevalence of non-GBS neonatal sepsis was 1.2 per $1,000(36$ of 31,133$)$ live births before and was 1.1 per 1,000 ( 32 of 28,733) live births after institution of the CDC protocol $(P=\mathrm{NS})$. The rates of sepsis involving E. Coli, Enterococcus, $K l e b s i e l l a$, and Pseudomonas species were not different. The prevalence of gram-negative sepsis was 0.6 per 1,000 live births before and 0.7 per 1,000 live births after institution of the CDC protocol $(P=\mathrm{NS})$. Likewise, the prevalence of non-GBS grampositive sepsis was 0.5 per 1,000 live births before and 0.4 per 1,000 live births after institution of the CDC protocol $(P=\mathrm{NS})$. Conclusions: Institution of a protocol for GBS antibiotic significantly decreased the rate of GBS neonatal sepsis, but did not increase the rate of non-GBS neonatal sepsis.

\section{VAGINAL DEFENSINS ARE ELEVATED IN WOMEN WITH UNRECOGNIZED UPPER GENITAL TRACT INFECTION}

Harold C. Wiesenfeld, R. Phillip Heine, Marijane A. Krohn, Sharon L. Hillier, Antonio Amortegui, Richard L. Sweet. University of Pittsburgh/ Magee-Womens Research Institute, Pittsburgh, PA

Objective: Clinically unrecognized PID might be responsible for subsequent tubal factor infertility, but is difficult to detect. Human neutrophil peptides 1-3 (defensins) are small proteins specific to the human neutrophil. We determined whether defensins measured from vaginal fluid are elevated in women with unrecognized PID.

Study Design: 276 women at risk for upper genital tract infection were enrolled. Vaginal swabs were collected for gram stain (BV score), $\mathrm{pH}$, microscopy, Trichomonas vaginalis (TV) culture, and defensin assay. Cervical samples were assayed for chlamydia (CT) and gonorrhea (GC), and endometrial biopsies were obtained. Histologic endometritis, a marker for unrecognized PID, was diagnosed in the presence of 1 plasma cell/ $120 \mathrm{X}$ and $5 \mathrm{PMN}$ 's/400X. Defensins were measured by ELISA technique. Values were compared using non-parametric analysis. Results: The median defensins level in our cohort was $1101 \mathrm{ng} /$ $\mathrm{ml}$. Women with GC, TV or yeast had higher median defensins levels than women without these infections (GC: $2157 \mathrm{ng} / \mathrm{ml}$ vs $966 \mathrm{ng} / \mathrm{ml}, P=0.06$, TV: $2888 \mathrm{ng} / \mathrm{ml}$ vs $949 \mathrm{ng} / \mathrm{ml}, P<0.01$, yeast: $2129 \mathrm{ng} / \mathrm{ml}$ vs $858 \mathrm{ng} / \mathrm{ml}, P<0.05$ ). Bacterial vaginosis and chlamydia were not associated with elevated defensins. Women with histologic endometritis had higher median vaginal defensins levels than women without endometritis $(2187 \mathrm{ng} / \mathrm{ml}$ vs $949 \mathrm{ng} / \mathrm{ml}, P=0.03)$. Elevated defensins ( $>1101 \mathrm{ng} / \mathrm{ml})$ were associated with a 2.6 fold increased risk of endometritis $(95 \%$ confidence interval $1.1,6.4$ ) after adjustment for STDs, candidiasis, and frequent sexual activity. Age, race, menstrual cycle phase, douching, and contraception were not associated with elevated defensins levels. Defensins were not elevated in women with plasma cell endometritis (without endometrial neutrophils). Conclusion: Defensins in vaginal fluid are elevated in women with histologic endometritis independent of lower genital tract infection. Incorporation of this marker to detect clinically unrecognized PID needs to be explored.

Supported by R01 AI41624 from the National Institutes of Health
Friday, August 4, 2000

General Sessions

Scientific Session IV

10:30 - 11:00 AM

EVALUATION OF A RISK BASED STRATEGY TO PREVENT NEONATAL INFECTIONS WITH GROUP B STREPTOCOCCUS

Kevin Ault, Lisa Hess and Stephen Hunter. University of Iowa, Iowa City IA

Objectives: To evaluate our institution's policy to prevent invasive neonatal infections with Group B Streptococcus (GBS). In 1993, we adopted a strategy based on giving intrapartum chemoprophylaxis in pregnancies complicated by premature labor, prolonged rupture of membranes, maternal fever, maternal bacteriuria with GBS or a prior affected newborn. Ampillicin was used for chemoprophylaxis. Study Design: Potential cases of newborn infection were identified by searching databases belonging to hospital epidemiology, clinical microbiology and our neonatal intensive care unit. Cases were defined as positive cultures from the blood, cerebrospinal fluid, trachea or urine. Only infections occurring in the first seven days of life were considered. Deliveries from 1993 to 1998 constituted the study periods. These were the first five years after initiating our GBS policy. Deliveries from 1988 to 1992 were used as a control group. There were 8,073 deliveries in the first time period and 6,610 deliveries in the later time period.

Results: The rate of invasive GBS disease was 7.0 cases per 1,000 deliveries from 1988 to 1992. After initiating our GBS prevention policy, the rate of invasive GBS infections dropped to 2.2 per 1,000 deliveries $(P<0.005$ by chi square analysis). Rates of invasive disease due to gram negative bacteria were unchanged in the two time periods: 1.5 per 1,000 deliveries vs. 1.1 per 1,000 deliveries. Conclusions: At our institution, we have decreased the rate of invasive GBS neonatal disease by approximately $60 \%$. Our successful strategy is based on using intrapartum ampillicin as chemoprophylaxis to mothers with key obstetrical risk factors. This policy did not affect the rate of newborn infections with gram negative bacteria.

\section{ASSESSMENT OF PLASMA, VAGINAL AND CERVICAL HIV-1 VIRAL LOAD THROUGHOUT THE MENSTRUAL CYCLE IN HIV INFECTED WOMEN \\ D. Money, Y. Arikan, V. Remple, P. Birch, C. Sherlock, D. Burdge}

Objectives: To determine: the menstrual cycle variations in; 1) levels of HIV plasma viral load; 2) the level of vaginal and cervical HIV viral load; 3) The viral genotype in plasma versus serum.

Methods: HIV infected women attending the Oak Tree Clinic, B.C., Canada, who were known to have regular menstrual cycles and stable disease, participated At enrolment, demographic, medical and STD history was documented. At the initial visit (Day 1 of menses), CD4, pap smear, vaginal gram stain were done. At initial and at follow up visits, plasma viral load, cervical viral load and vaginal viral load samples were taken. Ovulatory cycles were established by serum estradiol and progesterone levels.

Results: Fourteen women were followed over 2 cycles between September 1997 and June 1998. Mean age was 35.2 years (25-44). 
Nine of the 14 women were on antiretroviral therapy ( 3 on dual nucleosides and 6 on triple protease inhibitor combinations). HIV status: median CD4 of 355 (range 100 to 720 ); median viral load was 14,000 copies $/ \mathrm{ml}$ (range: $<400->750,000$ ). Fifteen ovulatory cycles were available for analysis in which viral load was detectable. Viral loads were expressed as $\log 10$ values and compared from follicular to periovulatory to luteal phase. No trends were seen in the minor fluctuations observed from phase to phase. When early follicular was compared to mid luteal phase, there was no significant difference in $\log 10$ viral loads. Genital tract viral load data has not been completely analysed.

Conclusions: Variations in HIV-1 RNA levels in plasma do not seem to be correlated with phases of the menstrual cycle.

Saturday, August 5, 2000

General Sessions

Scientific Session $V$

9:00 - 10:15 AM

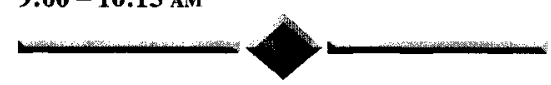

\section{INFECTION AND INFLAMMATION IN PERSPECTIVE: ETIOLOGIC CATEGORIES OF PRETERM BIRTH IN DENVER}

J.G. McFee, M. Orleans, D. Lezotte, J. McGregor Denver Health, University of Colorado School of Medicine, Denver, CO

Objective: Estimate the proportions of primary clinical causes of preterm birth $<35$ weeks gestation (PTB) and low birth weight (LBW) $<2000$ grams in three differing community hospitals.

Methods: Study hospitals included A) a large public hospital, B) a private hospital with assisted reproduction (AR) services, and C) a large HMO. Each case was reviewed and assigned to one of six principal etiologic categories: 1) idiopathic labor 2) pPROM 3) hemorrhage 4) preeclampsia 5) multiple gestation or 6) other conditions, including primary chorioamnionitis (PCAM) was diagnosed only after amniocentesis or placental culture proven infection.

Results: During this 3-year study there were 25,712 births. 426 births, including 478 infants were analyzed. $\mathrm{PTB} / \mathrm{LBW}$ was more common at $\mathrm{A}(2.27 \%)$ than at $\mathrm{B}(1.69 \%)$ or $\mathrm{C}(1.60 \%)(P=0.0016)$. More black and Hispanic women delivered at $\mathrm{A}(80 \%)$. In hospital $\mathrm{A}$, more cases delivered because of pPROM (27\%) or idiopathic labor $(28 \%)(P=$ $0.003)$. Primary clinical chorioamnionitis (PCAM) was diagnosed occurred more commonly at hospital A) $5 \%$ vs C) $1.3 \%$ vs B $) 0 \%(P=<$ $0.05)$. Multiple gestation, was more common at hospital $\mathrm{B}(25 \%)$ and $\mathrm{C}(17 \%)$ than at $\mathrm{A}(11 \%)(P=0.027)$. Preterm births were more often "indicated" at $\mathrm{C}(50 \%)$ than at $\mathrm{A}(29 \%)(P=0.002) . \mathrm{C} / \mathrm{S}$ rates for these early births differed between $\mathrm{A}(42.2 \%)$ and $\mathrm{B}(57.1 \%) P=0.03$

Conclusion: PTB from idiopathic PTL, pPROM and primary chorioamnionitis wasassociated with over 55\% PTB/LBW at the public hospital. Many of these births are linked to possibly preventable or remediable infection/inflammation. Multiple gestation was associated with fully $25 \%$ of cases at one private hospital. Efforts to reduce risks of LBW/PTB can be informed by knowledge of local etiologic factors. This knowledge can be utilized in focused local efforts to reduce $\mathrm{PTB} / \mathrm{LBW}$.

ACQUISITION OF BACTERIAL VAGINOSIS AMONG A LONGITUDINAL COHORT OF NON-PREGNANT WOMEN Marijane A. Krohn, Leslie A. Meyn, Sharon L. Hillier, University of Pittsburgh/Magee-Womens Hospital, Pittsburgh, PA
Objectives: The purpose of this study was to examine the risk factors associated with acquisition of bacterial vaginosis (BV) in a longitudinal cohort of non-pregnant women.

Study Design: Non-pregnant women between the ages of $18-30$ were enrolled at 3 clinics from 1998-2000. Demographic and behavioral interview data, a vaginal swab for the culture of genital microorganisms, and a vaginal smear were obtained. The swabs were inoculated onto blood agar plates and the vaginal smear was Gram stained and evaluated for BV according to the Nugent criteria. The collection of interview data and vaginal specimens were repeated 4 months from enrollment. Acquisition of $\mathrm{BV}$ was defined by a normal or intermediate Gram stain score at enrollment and a BV score at the 4-month visit. Results: Of the 455 women who were negative for $\mathrm{BV}$ at the enrollment visit, $75(16.5 \%)$ acquired BV by the 4-month visit. The characteristics that were univariately associated with acquisition of BV were non-white race, smoking, having 2 or more sex partners in the last 4 months, the absence of vaginal $\mathrm{H}_{2} \mathrm{O}_{2}$-producing lactobacillus at enrollment, and an intermediate Gram stain score at enrollment. In a logistic regression model containing these 5 factors, non-white race and smoking remained significantly associated with $\mathrm{BV}$ acquisition with odds ratio (OR) of 1.9 (95\% confidence interval (CI); 1.1-3.1) and 2.0 (CI; 1.2-3.4), respectively. Having an intermediate Gram stain score and 2 or more sex partners were also statistically significant with ORs of 4.3 for both and CIs of (1.5-12.6) and (2.4-7.6), respectively.

Conclusions: These findings suggest that BV status changes during a short interval and that behavioral factors affecting the vaginal ecosystem are involved in the change.

\section{OBSTETRICAL COMPLICATIONS, MATERNAL/FETAL TOXICITIES, AND VERTICAL TRANSMISSION IN COMBI- NATION ANTIRETROVIRAL-TREATED PREGNANT WOMEN \\ DM Money, GP Meneilly, VP Remple, JC Forbes, DR Burdge}

Objectives: To assess maternal complications, fetal adverse effects, and rate of vertical transmission in a cohort of HIV infected women treated with combination antiretroviral therapy (ART).

Methods: All HIV infected, pregnant women on combinationART( 2 drugs) seen at Oak Tree Clinic (OTC), tertiary referral centre in B.C., Canada, between January 1995 and December 1999 were included in the study. All women had repeated virologic and toxicity assessment throughout pregnancy and immediately postpartum. All women had detailed anatomic ultrasounds at 18 wks gestation and had serial ultrasounds for fetal growth and amniotic fluid. Mode of delivery \& indication, peripartum CD4, and viral load were assessed. All infants were evaluated at OTC.

Results: Thirty eight HIV-infected pregnant women seen at OTC took combination ART in pregnancy. Thirteen $(34 \%)$ were on dual nucleosides. Six $(16 \%)$ were on dual nucleoside/NNRTI combinations and $16(42 \%)$ were on dual nucleoside/protease inhibitor combinations. Three ( $8 \%$ ) were on greater than 3 drugs (range 4-6). Pregnancy outcomes were: $2(5 \%)$ spontaneous abortions, $4(10 \%)$ therapeutic abortions, $6(19 \%)$ preterm deliveries, and $26(81 \%)$ term deliveries. Of the live births, 11(34\%) were vaginal deliveries, and $21(66 \%)$ were caesarean sections: $11(52 \%)$ for obstetrical and $10(48 \%)$ for HIV indications. Maternal toxicities included: GI (41\%), rash/pruritis (13\%), and anemia (3\%). Antenatal complications included: IUGR ( $9 \%)$, oligohydramnios $(9 \%)$, preterm labour $(16 \%)$, hypertension $(6 \%)$, and abruption $(9 \%)$. The vertical transmission rate was $0 \%$. Viral load at delivery was $<400$ copies $/ \mathrm{ml}$ in $72 \%$.

Conclusions: Despite a $0 \%$ rate of vertical transmission, multiple maternal/fetal complications were noted in these pregnancies. HIV positive pregnant women treated with combination ART require 
monitoring of both maternal toxicity and fetal well-being. Further study is warranted.

\section{THE ROLE OF ETHNICITY AND VAGINAL LACTOBACILLI IN GONORRHEA INFECTION}

Sharon L. Hillier, Harold C. Wiesenfeld, Marijane A. Krohn, Daniel V. Landers, Richard L. Sweet. University of Pittsburgh/MageeWomens Hospital, Pittsburgh, PA

Objective: To evaluate the role of ethnicity and lactobacilli in susceptibility to gonorrhea in women.

Study Design: 887 women with lower genital tract symptoms or contact to STDs were recruited. Neisseria gonorrhoeae was detected by cervical culture, Chlamydia trachomatis was detected by PCR, and Trichomonas vaginalis by broth culture. Lactobacilli were categorized by the relative number of large Gram positive rods observed in Gram-stained vaginal smears. Structured questionnaires were administered to determine self-identification of race, numbers of sexual partners, marital status and condom usage.

Results: A total of 47 (5.7\%) of the women had gonorrhea, 94 (11.5\%) had chlamydia and $11.8 \%$ had trichomoniasis. The presence 3-4+ lactobacilli was associated with a decreased frequency of gonorrhea $(4 / 217,1.8 \%)$ compared to women having $1-2+$ lactobacilli $(16 / 298$, $3.4 \%)$ and those having no lactobacilli on Gram stain $(27 / 310,8.7 \%$, $P=0.001$ ). There was no statistically significant relationship between Lactobacillus morphotypes and chlamydia or trichomoniasis. White and non-white women had an equal risk of gonorrhea after stratifying by vaginal lactobacilli.

\begin{tabular}{|c|c|c|c|c|c|}
\hline \multirow[b]{3}{*}{ Lacto on Grain slain } & \multirow[b]{3}{*}{ Race } & \multicolumn{2}{|c|}{ Gonorrhea } & \multirow{2}{*}{\multicolumn{2}{|c|}{$\mathrm{OR}(95 \% \mathrm{Cl})$}} \\
\hline & & \multirow{2}{*}{$\begin{array}{c}\text { Yes } \\
\mathrm{n}=47\end{array}$} & \multirow{2}{*}{$\begin{array}{c}\text { No } \\
\mathrm{n}=775\end{array}$} & & \\
\hline & & & & Unadjusled & Adjusted" \\
\hline \multirow[t]{2}{*}{ None } & Non-white & 18 & 186 & $8.3(1.1-6.1)$ & $9.8(1.3-75)$ \\
\hline & White & 9 & 94 & $8.2(1.1-64)$ & $10.0(1.2-82)$ \\
\hline \multirow[t]{2}{*}{$1-2+$} & Non-white & 11 & 174 & $5.6(0.7-43)$ & $6.8(0.9-55)$ \\
\hline & White & 5 & 108 & $4.2(0.5-35)$ & $5.0(0.6-45)$ \\
\hline \multirow[t]{2}{*}{$3-4+$} & Non-white & 3 & 120 & $2.3(0.2-22)$ & $2.7(0.3-27)$ \\
\hline & White & 1 & 93 & Ref & Ref \\
\hline
\end{tabular}

${ }^{*}$ ddjusted for condom use, age, number of sex partners in the past 3 months

Conclusions: Absence of lactobacilli increased the risk of gonorrhea independent of ethnicity. These data support published studies demonstrating that women vaginally colonized by Lactobacillus have decreased acquisition of gonorrhea and further suggest that ethnic differences in the prevalence of gonorrhea observed in the United States may be attributable to the decreased levels of lactobacilli found in ethnic minority populations.

UTILITY OF PCR INTHE DIAGNOSISAND MANAGEMENT OF NORMAL pH, KOH, AND CULTURE-NEGATIVE CANDIDA VAGINITIS. A LONGITUDINAL STUDY IN 27 PATIENTS

Jose A. Vazquez, Stephanie Yoon, Debbie Leaman, Robert A. Akins, and Jack D. Sobel. Wayne State University School of Medicine, Detroit, MI

Objective: A major challenge in clinical practice is that of a subpopulation of women with vulvovaginal signs and symptoms, normal $\mathrm{pH}$, negative saline and $\mathrm{KOH}$ examination. The goal is to evaluate the utility of PCR in the diagnosis and management of this challenging group of patients.
Study Design: 136 vaginal swabs were obtained longitudinally from 107 patients with signs and symptoms of vaginitis. 27/107 patients had 2 or more sequential vaginal swabs, while 80 patients had one swab evaluated. All swabs were evaluated by $\mathrm{KOH}$, plated on Sabourauds Dextrose agar and CHROMAgar. In addition, all swabs underwent PCR assays using Candida specific primers. Culture positive and negative control swabs were evaluated simultaneously. All tests were performed in triplicate to ensure validity and reproducibility. Results: Of the 136 swabs, 20 were KOH $(+), 34$ were culture positive, while 114 were PCR $(+)$. Of the swabs that were culture $(+)(34), 31$ were $\mathrm{PCR}(+)$, a false negative rate of $<9 \%$. Of the culture and microscopy negative swabs $(100), 91$ were $\mathrm{PCR}(+), 7$ were PCR(). $24 / 27$ patients with sequential isolates shared clinical correlation with the PCR results. In $3 / 27$ patients the PCR results did not correlate with the clinical characteristics of the patient and they could have been false-positive or false-negative results.

Conclusion: The use of molecular techniques such as PCR may facilitate the management of this subpopulation of symptomatic women with microscopy and culture negative vaginitis. Although standard bacteriology is negative, low colony counts of cells may be present in the vagina and this may be enough to produce manifestations of vaginitis, yet the colony numbers are below the limits of detection with standard microbiologic test. In the future, PCR technology may have value in resolving a diagnostic and therapeutic dilemma in clinical practice.

Saturday, August 5, 2000

General Sessions

Scientific Session VI

10:30 - 11:15 AM

\section{INVASION OF HELA EPITHELIAL CELLS BY GROUP B STREPTOCOCCUS ISOLATES FROM NEONATAL BLOOD AND THE MATERNAL GENITAL TRACT}

GJ Locksmith, R Selvarangan, BJ Nowicki, University of Texas Medical Branch, Galveston, Texas

Objectives: To compare cellular invasion and between GBS isolates causing neonatal sepsis and those colonizing the lower maternal genital tract.

Study Design: We obtained 8 different strains of group B streptococcus from neonatal blood cultures and 9 different strains from routine maternal lower genital tract cultures. Bacterial suspensions from each sample were added to a monolayer of HeLa epithelial cells, a cervical squamous cell carcinoma line, and incubated. After treatment with gentamicin and washing, the cells were lysed and the invasive bacteria plated onto blood agar. Colony counts between the two groups were adjusted for the concentration of bacteria in the original suspension and compared using a MannWhitney rank sum test.

Results: All GBS strains invaded HeLa cells to a high degree (range: $600-14,600$ colonies/well). The extent of invasiveness between the strains causing neonatal sepsis (median: 1825 , interquartile range: $1200-5525$ colonies/well) and those colonizing the maternal lower genital tract (median- 1800, interquartile range: 1088-3138 colonies/ well) was not significantly different $(P=0.47)$. After adjusting for the bacterial concentration the original suspension, the difference remained non-significant $(P=0.31)$

Conclusions: GBS strains that merely colonize the maternal genital tract and those that cause serious disease in neonates invade HeLa cells. No difference in the extent of invasion was noted. 
THE EFFECT OF HIGHLY ACTIVE ANTIRETROVIRAL THERAPY (HAART) ON CIN IN HIV-INFECTED WOMEN: A CASE-CONTROL STUDY

Rajiv Shah, Joan Murphy, and Sharon Walmsley

Background: Human papilloma virus (HPV) is associated with cervical intraepithelial neoplasia and is highly prevalent in women infected with HIV. HIV positive women have approximately five times higher risk than seronegative women with regard to incidence of squamous intraepithelial lesions (SIL). HPV related cervical disease may also progress faster and regress more slowly in women with HIV infection. Most of these studies were done in the era before the use of HAART. With newer antiretroviral therapies, the incidence of opportunistic infections and death has declined. There has only been one small study to date examining the course of CIN over 5 months in HIV positive women on HAART. Given the paucity of information on the natural history of CIN in the era of HAART we conducted this study

Objective: (1) To examine the effect of antiretroviral therapy on the rates of progression, recurrence and regression SIL in HIV positive women; (2) To compare these rates with HIV seronegative patients. Methods: A case-control study of 19 cases and 19 controls was performed. The cases consist of HIV positive women who were referred to a single gynecologic oncology clinic, with documented CIN by biopsy. They were subdivided into those who did or did not receive HAART in the months after diagnosis of cervical dysplasia. The control group consists of HIV negative women who were referred to the same clinic for follow-up of an abnormal pap smear and/or documented CIN. The intervention consisted of either laser vaporization, laser cone, LEEP, or observation. All patients were followed up for 15 months after their intervention to deal with their squamous intraepithelial lesion.

Results: Of the $19 \mathrm{HIV}$ positive patients, 9 patients had regression of their dysplasia whereas 10 patients had persistent disease. Of the HIV negative controls 17 patients had regression of their disease and only 2 persisted. Overall HIV negative women did better than HIV positive women in clearing their disease $(P=0.013)$. When comparing HIV positive women on HAART to controls there was no statistically significant difference in the rates of regression between the two groups. However, HIV positive women not on therapy had lower rates of regression than their controls $(37.5 \%$ of cases regressed compared to $100 \%$ of controls who regressed; $P=0.026$ ).

Conclusion: Our study is the first to document the course of CIN in HIV positive women on HAART for up to a 15-month follow-up post treatment for their dysplasia. Our study confirms previous finding that HIV positive women have higher rates of persistence of cervical dysplasia compared to HIV seronegative women. We were able to show that HIV positive women not on antiretroviral therapy had a worse prognosis than did their seronegative counterparts. No significant difference in the course of CIN was detected between HIV positive patients on HAART compared to seronegative women. Therefore, HAART may improve the history of CIN in HIV positive women.

\section{PATTERN OF GESTATIONAL PYELONEPHRITIS IN THE AGE OF ANTIBIOTIC RESISTANCE}

T. Wen, J. Pipe Department of OB/GYN, The University of Texas Health Science Center at San Antonio, San Antonio, Texas

Objectives: To assess the antibiotic resistance pattern of the bacteria that cause gestational pyelonephritis (GP) and their association with bacteremia.

Study Design: Women with pyelonephritis during their pregnancy or within 4 weeks of delivery were assessed in this ongoing analysis. The pattern of infectious microbials and their antibiotic resistance was evaluated. Clinical factors were evaluated in regard to resistance pattern and risk for bacteremia. Descriptive statistics and Fisher exact or chi-square tests were used.

Results: To date, 58 women have been analyzed. The clinical distributions of women with GP are as follow: nulliparous (39.7\%), trimester- first (24.1\%), second (39.7\%), third (22.4\%), postpartum $(13.8 \%)$. The antibiotic resistance rate among microbials cultured in the urine and blood are $63.8 \%$ and $61.5 \%$, respectively. There were no differences in the rates of bacteremia or resistance by trimester. There is an association between bacteremia and microbials which express antibiotic resistance $(P=0.04)$.

\begin{tabular}{lccc}
\hline $\begin{array}{l}\text { Bacterial infection pattern (\%) } \\
\text { Organism }\end{array}$ & $\begin{array}{c}\text { Urine } \\
\text { Nonpregnant }\end{array}$ & Bacteremia & Genital \\
\hline E. coli & 87.9 & 23.5 & 42.2 \\
GBS & 1.7 & 0 & 13.3 \\
K. pneumoniae & 5.2 & 2.0 & 4.4 \\
P. mirabilis & 1.7 & 2.0 & 2.2 \\
Enterococcus & 0 & 0 & 8.8 \\
Other & 8.6 & 2.0 & 13.3 \\
\hline Antibiotic resistance pattern (\%) & Antibiotics & Urine & Blood \\
\hline Ampicillin & 58.6 & 38.4 & 52 \\
Amp-sulbact. & 22.4 & 15.4 & 26 \\
Cephalothin & 17.2 & 15.4 & - \\
Cefazolin & 3.4 & 0 & 7 \\
Trimeth-sulfa & 24.1 & 30.8 & 28 \\
Nitrofurantoin & 1.7 & 0 & 2 \\
Levoflaxacin & 0 & 0 & 2 \\
\hline
\end{tabular}

Conclusions: $E$. coli is the predominant pathogen in gestational pyelonephritis. Women with gestational pyelonephritis infected with bacteria that express antibiotic resistance are more likely to develop the complication of bacteremia.

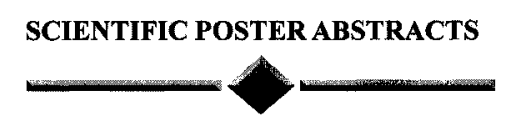

LOCAL HUMORAL IMMUNE RESPONSES TO CANDIDA ALBICANS IN PATIENTS WITH SYMPTOMATIC VERSUS ASYMPTOMATIC VAGINAL COLONIZATION

C. Allen Black. Harold C. Wiesenfeld, Marilyn R. Cost, Sharon L. Hillier. University of Pittsburgh/Magee-Womens Research Institute, Pittsburgh, PA

Objectives: To determine the role of Candida albicans specific $\mathrm{IgG}_{1-4}, \operatorname{IgA}$, IgE and IgM in patients suffering from symptomatic vaginitis versus those with asymptomatic vaginal yeast colonization and to correlate changes in immunoglobulin levels with pathology. Study Design: Patients (18-45 yr) with culturable C. albicans were divided into two groups $(n=12)$, those with clinically significant vulvovaginal candidiasis and those with significant yeast colonization but no clinical disease or symptoms. Swabs were taken from vaginal canal and cultured for C. albicans. Also, serum and vaginal mucus were collected. Recoverable vaginal cells from the swab were stained with $H \& E$ and examined for hyphae versus blastoconidia phase yeast and possible lymphocytes.An antigen extract was made by sonicating the individual's yeast cell cultures. This extract was used in as the coat antigen in ELISA. Patient's serum and vaginal mucus were assayed for antigen-specific $\operatorname{IgG}{ }_{1-4}, \operatorname{IgA}, \operatorname{IgE}$ and $\operatorname{IgM}$. The concentration of antibody was extrapolated as an endpoint titer. Patients were excluded for concomitant bacterial infections and HIV. 
Results: All women, regardless of symptomology, had detectable serum antigen-specific IgG, IgA and IgM (average endpoint range 10,000-20,000) against the colonizing strain of $C$. albicans. In the vagina, antigen-specific $\operatorname{IgG}_{14}$ were detected in both symptomatic and asymptomatic patients but $\operatorname{IgG}_{2}, \operatorname{IgG}_{3}$ and $\operatorname{IgG}_{4}$ were elevated in asymptomatic patients. In vaginal mucus of the vaginitis patients, C. albicans-specific $\lg \mathrm{A}$ and $\lg \mathrm{M}$ were detected (endpoint range $8000-12,000$ ). In one third of the vaginitis patients, local C. albicans specific IgE was detected but at low levels. No detectable vaginal lymphocytes or eosinophils were found upon microscopic examination in any patients.

Conclusions: The local antibody response to $C$. albicans in symptomatic versus asymptomatic patients differs but this variation may be due to inflammation and transudation of. serum immunoglobulin. C. albicans specific IgE can be detected locally in onethird of vaginitis patients and may explain why a subset of women experience candida vaginitis instead of asymptomatic colonization. However, in the majority of women with vaginitis, $\operatorname{IgE}$ is not detectable.

\section{DEVELOPMENT OF A MODEL FOR "CHRONIC" INTRA- UTERINE INFECTION IN THE RABBIT}

R Gibbs, J Davies, R McDuffie and K Leslie. University of Colorado Health Science Center, Denver, CO

Objectives: In the rabbit intracervical inoculation of $E$. coli at $70 \%$ gestation reproducibly leads to acute infection with fever and pregnancy loss developing within 30 hours, accompanied by positive cultures and histologic and biochemical evidence of infection and inflammation (Dombroski, 1990; McDuffie, 1992). When antibiotic therapy has been added beginning 0.5 hours after inoculation, a model of "chronic" infection has been reported for up to 5 days following inoculation. This is accompanied by positive cultures in the amniotic fluid in aproximately half of cases and by a significant increase in periventricular white matter lesions in the pups (Yoon, 1997). Our overall goal is to understand the interaction of "chronic infection" and fetal sequelae. Our immediate objective is to develop a reproducible model for "chronic" intrauterine infection in the rabbit.

Study Design: With methods previously reported, New Zealand White Rabbits at $70 \%$ gestation (day $20-21$ of 31 day gestation) were inoculated intracervically with $10^{3-4}$ cfu $E$, coli per uterine horn. At varying intervals after inoculation, antibiotic therapy was initiated with ampicillin sulbactam $(100 \mathrm{mg} / \mathrm{kg} / \mathrm{d}$ in 3 divided doses) until conclusion of the experiment. Primary outcomes were positive cultures and histologic inflammation, which was assessed using a semiquantitative histologic inflammation (HI) score (based upon necrosis, inflammation, congestion, and edema, range $(0-12)$.

Results

Table 1. Results with antibiotic therapy beginning 0.5 hr after inoculation

\begin{tabular}{lccc}
\hline & \multicolumn{3}{c}{ Day of sacrifice after inoculation } \\
\cline { 2 - 4 } & Day 1 & Day 3 & Day 5 \\
\hline Uterine culture positive & $5 / 8$ & $0 / 6$ & $1 / 8$ \\
Other doe culture positive & $0 / 8$ & $0 / 6$ & $0 / 8$ \\
Fetal cultures positive & $0 / 8$ & $0 / 6$ & $0 / 8$ \\
HI score - uterus & 1.1 & 1.8 & 2.4 \\
HI score - placenta* & 0.7 & 1.8 & 2.4 \\
HI score - lung & 0.8 & 0.3 & 0.5 \\
\hline
\end{tabular}

$* P=0.003$.
Table 2. Results at 5 days with antibiotic therapy beginning 2 hr after inoculation

\begin{tabular}{lc}
\hline Blood culture positive & $2 / 16$ \\
Peritoneal culture positive & $4 / 16$ \\
Uterine culture positive & $7 / 16$ \\
Amniotic culture positive & $3 / 16$ \\
Fetal brain culture positive & $6 / 14$ \\
Fetal heart culture positive & $4 / 14$ \\
HI score - uterus & $2 / 2$ \\
HI score - placenta & 3.7 \\
HI score - lung & 1.8 \\
\hline
\end{tabular}

With a 4 hr delay in antibiotic therapy in 6 animals, uterine cultures were positive in $3(50 \%)$ and fetal cultures were positive in $1(16 \%)$. HI scores were similar to those with $2 \mathrm{hr}$ delays.

Conclusions: These data show the importance of clearly defining an experimental model for "chronic" infection without spontaneous delivery can be established by administering delayed antibiotic therapy. However, we found delay of longer than $0.5 \mathrm{hr}$ was required to establish evidence of "chronic" infection. Further, even though cultures were frequently positive in genital and fetal tissues, there was minimal histologic inflammation.

\section{SUCCESSFULTREATMENT OFA HEPATITIS C-INFECTED PREGNANT WOMAN WITH INTERFERON-ALPHA TO PREVENT VERTICAL TRANSMISSION}

J Trotter, J Davies, P Wilkies, R Gibbs. Division of Gastroenterology/ Hepatology, Department of Medicine and Department of Obstetrics and Gynecology, University of Colorado Health Sciences Center, Denver, CO

Introduction: Hepatitis $\mathrm{C}$ virus $(\mathrm{HCV})$ infection is common in the US, affecting 1-2\% of the population. Many of these patients are women of reproductive age and may transmit HCV to their child during pregnancy and/or childbirth. Currently, there are no recognized strategies to prevent vertical transmission of $\mathrm{HCV}$. While interferon and interferon/ribavirin therapies are effective in the eradication of $\mathrm{HCV}$, both drugs are considered to be contraindicated during pregnancy There are no reported cases of intentional interferon treatment during pregnancy to prevent vertical transmission of $\mathrm{HCV}$. We report a patient who previously had transmitted HCV to her first child. She presented to our Hepatology clinic 30 weeks into a subsequent pregnancy with active $\mathrm{HCV}$ viremia. The mother was treated with interferon monotherapy during the last two weeks of the pregnancy. After this time HCV was undetectable and she subsequently gave birth to a child who was HCV-RNA negative.

Case Report: JT is a 23-year-old white female who was first diagnosed with hepatitis $C$ in 1994. She had given birth to a child 12 months previously who became hepatitis $C$ positive. She had a liver biopsy in $12 / 98$ that showed stage 2 , grade $2 \mathrm{HCV}$. In this trial she received interferon for sdix weeks during which time her HCV-RNA decreased to undetectable levels. The patient stopped therapy herself because of personal problems. She subsequently became pregnant and then presented to the Hepatology clinic 9 months later when she was 30 weeks pregnant, requesting evaluation for antiviral therapy to prevent vertical transmission to her child. Laboratory findings were: serum creatinine $-0.8 \mathrm{mg} . \mathrm{dl}$; aspartate aminotransferase $-21 \mathrm{IU} / \mathrm{I}$; alanine aminotransferase - 18IU/I; alkaline phosphatase - 72IU/I; bilirubin - $0.1 \mathrm{mg} . \mathrm{dl}$; albumin $-2.9 \mathrm{~g} / \mathrm{dl}$; white blood cell count $-5 /$ $9 / \mathrm{mm}^{3}$; hematocrit $44 \%$; platelet count $/ \mathrm{mm}^{3}-167,000$; prothrombin time - 11.9 seconds; hepatitis B surface antigen - negative; hepatitis C antibody - positive; HCV-RNA-4,000,000 copies/ml. The patient 
was started on interferon monotherapy $3 \mathrm{mU}$ sq qd while hospitalized at 36 weeks gestation. Ribavirin was not used because the patient had previously eradicated virus after two weeks of interferon monotherapy. The patient received a total of 14 doses of interferon ( $3 \mathrm{mU}$ sq qd) after which time another HCV-RNA level was measured and determined to be undetectable. Before induction of labor was started, and within 48 hours of the report of viral eradication, the patient went into spontaneous labor and delivered a health male infant. She discontinued therapy at the time of delivery. The infant was positive for hepatitis $\mathrm{C}$ antibody at one month. However, the baby's HCV-RNA was undetectable at 3 months.

Conclusion: Interferon monotherapy during the third trimester may be an effective treatment strategy to prevent vertical transmission in selected HCV-infected mothers. Interferon was tolerated well in our patient.

\section{CORRELATION BETWEEN NUGENT SCORE OFVAGINAL GRAM SMEAR AND QUANTITATIVE AND QUALITATIVE VAGINAL CULTURE IN PREGNANT WOMEN}

Mary L. Delaney M.A.P. Study Group and Andrew B. Onderdonk

Objectives: To evaluate vaginal Gram stain smears using the Nugent criteria, to perform quantitative and qualitative cultures on vaginal samples, and to compare the Nugent score to the microbiologic findings.

Study Design: The vaginal microflora is a dynamic ecosystem in which both the types and concentrations of organisms present are indicative of the health of the individual. The Nugent criteria, designed to detect bacterial vaginosis (BV) by evaluating vaginal microflora, is a standardized method of Gram stain interpretation. Vaginal swab smears are graded based on the presence or absence of Lactobacillus morphotypes, Gram variable/negative rods, and curved Gram-negative rods. In the current study, 202 vaginal smears from pregnant subjects were scored by two independent evaluators using the Nugent criteria. In addition, quantitative and qualitative vaginal cultures were performed and results expressed as $\log _{10}$ CFU/gram of vaginal secretions. The Nugent scores were compared to the microbiologic findings.

Results: The prevalence of $\mathrm{BV}$, intermediate or normal vaginal flora as seen by Gram stain was $10 \%, 20 \%$ and $70 \%$, respectively. The mean score of the BV group was 7.63 $1.27,4.61 \quad 0.86$ for the intermediate group and 1.51 0.95 for the normal group. A comparison of mean counts by Nugent score showed a strong correlation for both Lactobacillus spp. and Gram variable/negative rods. However, a comparison of individual counts and Nugent score showed a broad range of values for any given Nugent score forLactobacillus spp. while the Gram variable/negative rods had a narrow range. Further analyses examining Peptostreptococus, a genera not comprising the Nugent score, showed a strong correlation between total count and Nugent score. The concentration of hydrogen peroxide producing Lactobacillus did not appear to effect these correlations.

Conclusions: There is a strong correlation between the genera comprising the Nugent score, in particular with the Gram variable/ negative rods. Peptostreptococcus also shows a strong correlation suggesting this genus may play a role as an indicator of the health of the individual.

EFFECT OF DOUCHE SOLUTION INGREDIENTS ON VAGINAL MICROFLORA GROWING IN BATCH AND CONTINUOUS CULTURE

Robin A. Ross ${ }^{1}$ and Andrew B. Onderdonk ${ }^{2}{ }^{1}$ Channing Laboratory, Dept. of Medicine and Pathology, ${ }^{2}$ Brigham \& Women's Hospital and Harvard Medical School, Boston, MA
Objectives: Determine the effect of current and proposed douche solution ingredients on the growth of normal vaginal microflora. Study Design: Organisms representative of vaginal microflora (Lactobacillus acidophilus, Staphylococcus epidermidis, Prevotella bivia, Enterococcus faecium, Corynebacterium striatum) were tested individually in batch culture and in co-culture using continuous culture techniques. Under anaerobic conditions, compounds were added to growth medium simulating vaginal secretions and the concentration of each organism was determined at various times after inoculation. A predictive statistical model was used to determine whether the mixed vaginal microflora (MVF) became abnormal (GEE value). Current douche solution ingredients tested were germaben II, FD\&C blue \#1, D\&C red \#28, D\&C yellow \#10, fragrance \#36634214B, fragrance \#802331, fragrance florasynth \#S-1221, fragrance florasynth \#S-8649, and triton X-100/octoxynol 9. Proposed ingredients tested included citrate and tartrate buffers (SmithKline and Beecham Consumer Healthcare). If not otherwise noted, the initial medium $\mathrm{pH}$ in batch culture was 5.0 . In continuous culture the $\mathrm{pH}$ was maintained at 5.0.

Results: In batch studies, the current douche solution ingredients did not inhibit the growth of the strains tested. Citrate and tartrate buffers were evaluated at a $\mathrm{pH}$ of 4.5 and 5.5 using individual organisms. Both buffers had an effect on the growth of vaginal microflora to varying degrees, but only citrate at $\mathrm{pH} 4.5$ completely prevented growth of an organism, P. bivia. In continuous culture, only the addition of germaben II altered the microflora with an increase in GEE of 0.7 .

Conclusions: The current and proposed douche solution components tested did not alter the vaginal microflora sufficiently to result in an abnormal vaginal environment.

\section{EFFECT OF VAGINAL MICROENVIRONMENT ON IN VITRO FERTILIZATION (IVF) LIVE BIRTH RATES (LBR) AND EMBRYO TRANSFER (ET) CATHETER TIP CULTURE RESULTS \\ LO Eckert, DE Moore, DY Patton, KJ Agnew, DA Eschenbach}

Background: In a study of 91 women previously reported, ' IVF LBR had significant associations with ET catheter tip culture results. The over-all LBR was 29 (32\%) of 91 women.

Influence of ET catheter tip microbiology on the live birth rate in 91 women undergoing IVF

\begin{tabular}{lccc} 
Microorganism & $\begin{array}{c}\text { Livebirth in } \\
\text { culture } \\
\text { positive }\end{array}$ & $\begin{array}{c}\text { Livebirths in } \\
\text { ET culture } \\
\text { negative }\end{array}$ & $P$ \\
\hline $\begin{array}{c}\mathrm{H}_{2} \mathrm{O}_{2} \text {-producing } \\
\text { Lactobacillus } s p .\end{array}$ & $7 / 10(70 \%)$ & $22 / 81(27 \%)$ & 0.02 \\
\begin{tabular}{l} 
S. viridans \\
\hline
\end{tabular} & $1 / 17(6 \%)$ & $28 / 74(27 \%)$ & 0.02 \\
\hline
\end{tabular}

Objective: To further characterize the influence of both quantitative vaginal culture results and vaginal poly-morphonuclear lymphocytes (PMNs) on ET catheter tip culture results, and LBR.

Methods: Quantitative vaginal culture, vaginal Gram stain, and ET catheter tip cultures were obtained from 91 women undergoing IVF from May 1997 to May 1998. Vaginal smears were quantitated for PMNs using ocular micrometry of 5 non-adjacent HPF by an investigator blinded to culture results. Categorical variables were compared using Chi-square or Fisher's Exact tests as appropriate. Vaginal log concentrations (VLC) of specific bacteria were compared to catheter tip concentrations using Mann-Whitney U-test. 
Results: The VLC of $S$. viridans was $7.7 \quad 0.3$ for the 15 women with, and 6.30 .3 for the 36 women without catheter tip isolation of $S$. viridans $(P=0.005)$. The VLC of $\mathrm{H}_{2} \mathrm{O}_{2}+$ Lactobacillus $s p$. (LB) was 8.0 0.99 for the 9 women with, and $6.6 \quad 2.2$ for the 19 women without catheter tip isolation of $\mathrm{H}_{2} \mathrm{O}_{2}+\mathrm{LB}(P=0.07)$. In the 28 women conceiving, the VLC of $\mathrm{H}_{2} \mathrm{O}_{2}+\mathrm{LB}$ was 7.31 .7 in 25 women with a live birth and 4.92 .5 in 3 women who had a SAB $(P=0.1)$. The LBR was 15 (35\%) of 43 in those with 0-4 PMNs vs. 12 (25\%) of 47 in those with 5 PMNs $(P=0.3)$. Catheter tip culture results and vaginal PMNs are presented below.

\begin{tabular}{lcc}
\hline Catheter tip culture & $>5$ PMNs & $P^{*}$ \\
\hline $\mathrm{H}_{2} \mathrm{O}_{2}+$ Lactobacillus sp. & $3 / 8(38 \%)$ & ref \\
No growth & $26 / 46(57 \%)$ & 0.3 \\
S. viridans & $9 / 14(64 \%)$ & 0.2 \\
\hline
\end{tabular}

*each group compared to $\mathrm{H}_{2} \mathrm{O}_{2}+$ Lactobacillus sp., Chi-square for trend $=0.2$

Conclusions: These data demonstrate that vaginal flora does, and vaginal inflammation may, influence both IVF ET catheter tip culture results, and subsequent LBR from IVF. Further study of vaginal and cervical microbiology and inflammation and their influences on ET catheter tip culture results and LBR may suggest specific treatments to enhance IVF success rates.

Reference: Moore DE, Agnew KJ, Klein NA, et al. Bacteria in the Transfer Catheter Tip Influence IVF/ET Live Birth Rates. Presented at the ASRM Annual Meeting, September 25-30, 1999, Toronto, Ontario, Canada.

\section{VAGINAL-RECTAL COLONIZATION WITH GROUP A STREPTOCOCOCCI IN LATE PREGNANCY.}

Philip B. Mead, Washington C. Winn

Objectives: To determine the vaginal-rectal colonization rate with group A streptococci in late pregnancy.

Study Design: All patients delivering at a northern New England hospital over a 38 month period had 35-37 week vaginal-rectal swabs cultured for groupA and group B streptococci, using selective media and slide agglutination.

Results: 6944 screening cultures were obtained. 1393 were positive for group B streptococci, and 2 for group A streptococci, yielding colonization rates of $20.1 \%$ and $.03 \%$ respectively.

Conclusions: In this predominantly white northern New England population, vaginal-rectal colonization with group A streptococci is rare, occurring once in every 3,472 deliveries. An approach for managing this uncommon finding is presented.

\section{THE FREQUENCY OF ANTIBIOTIC RESISTANCE AMONG GROUP B STREPTOCOCCUS (GBS) ISOLATES OBTAINED FROM HEALTHY, ASYMPTOMATIC COLLEGE STUDENTS Shannon Manning, Betsy Foxman, Patricia Tallman, Carl Pierson and Mark Pearlman}

Objectives: GBS causes substantial morbidity and mortality in pregnant women and non-pregnant adults, and remains the most common cause of neonatal sepsis and meningitis. Colonization rates and antibiotic sensitivities have not been described among low risk, non-pregnant populations, particularly men.

Study Design: We describe the frequency of GBS antibiotic resistance to ten antimicrobials among 139 GBS isolates from 150 randomly selected healthy, asymptomatic male and female college students in 1998. Participants provided self-collected urine, rectal and vaginal specimens and completed a self-administered questionnaire including information on recent antibiotic use and sexual history. Antibiotic susceptibilities were determined using disk diffusion with Etest to confirm marginal results.

Results: Among the 49 students (33\%) colonized with GBS, 36\% $(10 / 28)$ of females and $19 \%(4 / 21)$ of males had GBS resistant to erythromycin, while $21 \%(6 / 28)$ of females and $10 \%(2 / 21)$ of males had GBS resistant to clindamycin. The differences in resistance by gender were not statistically significant. Of the 14 resistant isolates, $64 \%$ were resistant to both drugs, while the remaining strains were resistant to erythromycin only. Using pulsed-field gel electrophoresis (PFGE) analysis, those strains with erythromycin and clindamycin resistance represent $26 \%(6 / 23)$ of the total number of PFGE banding patterns. All GBS isolates were sensitive to penicillin, ampicillin, levofloxacin, synercid, and vancomycin. Screening for resistance to cefazolin, linezolid and imipenem is ongoing.

Conclusions: The antibiotic resistance rates among this population of healthy, asymptomatic college students are twice as high as those reported in the literature. This suggests there may be increasing problems associated with the prevention of GBS neonatal disease as this group of individual enters their childbearing years.

\section{SCREENINGAND TREATING FOR BACTERIALVAGINOSIS IN PREGNANCY: A SYSTEMATIC EVIDENCE REVIEW}

Jeanne-Marie Guise, Susan Mahon, Mikel Aickin, Mark Helfand, Oregon Health Sciences University Evidence-Based Practice Center for the US Preventive Srvices Task Force and the Agency for Healthcare Research and Quality

Objective: To assess the value of screening and vVaginosis (BV) in pregnancy.

Methods: We conducted a systematic review of the literature on screening for and treating BV in pregnancy. We identified seven randomized controlled trials of $\mathrm{BV}$ treatment that measured pregnancy outcomes. We applied a new graphical meta-analytic method to characterize and interpret conflicting results in randomized trials of the effect of BV treatment on adverse pregnancy outcomes such as preterm delivery, preterm premature rupture of membranes, low birthweight, spontaneous abortion, maternal endometritis, and neonatal sepsis. Specifically, we examined evidence from these trials on the relationship between risk status and effectiveness of screening and treating for $\mathrm{BV}$ in the general population and in high-risk groups. We used data from our meta-analysis to estimate the benefit or harms of screening average-risk and high-risk pregnant women.

Results: We found no benefit to BV screening and treatment in average-risk women for any pregnancy outcome. High-risk studies were statistically heterogeneous for the benefit of BV treatment. Comparisons of patient samples, treatment regimens, and study designs of all trials suggested that a subset of very high-risk pregnant women might benefit from screening and treating BV.

Conclusions: Randomized trials show no benefit to screening and treating BV all pregnant women for BV. There may be a subgroup of high-risk women that could benefit from BV screening and treatment.

POOR PREDICTIVE VALUE OF SYMPTOMS FOR DIAGNOSIS OF LOWER GENITAL TRACT INFECTIONS

Daniel V. Landers, Sharon L. Hillier, MarijaneA. Kroh, and R. Phillips Heine, University of Pittsburgh/Magee-Womens Hospital, Department of Obstetrics, Gynecology and Reproductive Sciences and Magee-Women Research Institute, Pittsburgh 
Objectives: To evaluate the usefulness of symptoms for identification of lower genital tract infections in women.

Study Design: 598 women reporting new lower genital tract complaints were asked questions about their symptoms. Clinical diagnoses were made using direct observation (mucopurulent cervicitis, MPC), wet mount (trichomoniasis, yeast vaginitis, clue cells), and assessment fo $\mathrm{pH}$ and amine. Laboratory testing for $N$. gonorrhoeae (GC), yeast and T. vaginalis (TV) was by culture, $C$. trachomatis (CT) by PCR and bacterial vaginosis (BV) by Gram stain.

Results: The most frequently reported symptoms were abnormal discharge $(64 \%)$, change in discharge $(53 \%)$, odor $(48 \%)$, itching $(32 \%)$, burning (18\%), and dysuria (12\%). The frequency of symptoms in women with clinically or laboratory-diagnosed infection is summarized below.

\begin{tabular}{|c|c|c|c|c|c|c|}
\hline & \multicolumn{6}{|c|}{ Presenting Symptoms } \\
\hline & $\begin{array}{c}\mathrm{Ab} \\
\text { discharge }\end{array}$ & $\begin{array}{c}\text { in } \\
\text { discharge }\end{array}$ & Odor & Itching & Burning & Dys \\
\hline Clinical DX & $n=381$ & $n=318$ & $n=290$ & $\mathrm{n}=192$ & $n=110$ & $\mathrm{n}=73$ \\
\hline$M P C n=104$ & $19 \%$ & $16 \%$ & $18 \%$ & $18 \%$ & $17 \%$ & $15 \%$ \\
\hline Trich $n=61$ & $10 \%$ & $11 \%$ & $12 \%$ & $12 \%$ & $13 \%$ & $13 \%$ \\
\hline$B V n=354$ & $62 \%$ & $65 \%$ & $73 \%$ & $51 \%$ & $54 \%$ & $56 \%$ \\
\hline Yeast $n=61$ & $14 \%$ & $16 \%$ & $8 \%$ & $31 \%$ & $19 \%$ & $13 \%$ \\
\hline Lab DX & $n=356$ & $\mathrm{n}=256$ & $n=204$ & $n=185$ & $\mathrm{n}=112$ & $n=73$ \\
\hline Yeast $\mathbf{n}=96$ & $17 \%$ & $21 \%$ & $18 \%$ & $23 \%$ & $24 \%$ & $18 \%$ \\
\hline Trich $\quad B V n=60$ & $12 \%$ & $15 \%$ & $17 \%$ & $11 \%$ & $15 \%$ & $15 \%$ \\
\hline$B V$ alone $n=211$ & $42 \%$ & $49 \%$ & $62 \%$ & $31 \%$ & $24 \%$ & $21 \%$ \\
\hline $\mathrm{GC} / \mathrm{CT}$ with $\mathrm{BV} \mathrm{n}=33$ & $5 \%$ & $7 \%$ & $10 \%$ & $4 \%$ & $5 \%$ & $5 \%$ \\
\hline $\mathrm{GC} / \mathrm{CT}$ no $\mathrm{BV} \mathrm{n}=30$ & $5 \%$ & $5 \%$ & $4 \%$ & $4 \%$ & $2 \%$ & $10 \%$ \\
\hline No infection $n=126$ & $19 \%$ & $22 \%$ & $23 \%$ & $25 \%$ & $34 \%$ & $32 \%$ \\
\hline
\end{tabular}

Conclusions: Because of the poor predictive value, presenting symptoms should not be used to guide treatment without diagnostic testing.

\section{FACTORS ASSOCIATED WITH HIGHER STD INFECTION} RATES IN WOMEN WITH UNDESIRED PREGNANCIES

JM Piper, RN Shain, ER Newton, ST Perdue, JD Champion, AEC Holden, Dept of Ob/Gyn, UTHSCSA, San Antonio, Texas

Objective: To identify risk factors associated with higher STD rates in women with undesired pregnancies.

Study Design: We have previously described higher rates of STD reinfection in high-risk minority women with undesired pregnancies (31\%), as compared to those with desired pregnancies $(11 \%)$, and nonpregnant women $(23 \%)$, enrolled in a randomized trial of a behavioral intervention to reduce STD recurrence. Participants were extensively questioned about their sexual behavior and tested for STDs at entry, 6, and 12 month follow-up. 549 women with know reinfection status for the cumulative study period ( $0-12$ months) were stratified into pregnant versus nonpregnant at entry, with pregnant women further stratified by whether or not they or their family had considered abortion (undesired $=$ she or her family considered abortion, desired $=$ did not consider abortion). Risk factors at followup potentially associated with reinfection were compared. Separate logistic regressions were performed for $0-6,6-12$, and $0-12$ month intervals to control for the impact of potential confounding factors (intervention effect, age, prior STDs) on the reinfection rates. Results of the $0-12$ month analyses are shown. Results:

\begin{tabular}{lcccc}
\hline $\begin{array}{l}\text { Cumulative Data } \\
(0-12 \text { months) }\end{array}$ & $\begin{array}{c}\text { Desired } \\
\mathbf{n}=104\end{array}$ & $\begin{array}{c}\text { Undesired } \\
\mathrm{n}=\mathbf{6 1}\end{array}$ & $\begin{array}{c}\text { Nonpregnant } \\
\mathbf{n}=384\end{array}$ & $\begin{array}{c}\mathrm{RR}(95 \%(\mathrm{CI}) \\
\text { from logistic regres. }\end{array}$ \\
\hline Multiple partners & $\mathbf{1 8 \%}$ & $\mathbf{2 7 \%}$ & $45 \%$ & $1.72(0.98-3.01)$ \\
Exclusively steady partners & $\mathbf{6 8 \%}$ & $57 \%$ & $51 \%$ & $1.75(1.01-3.05)$ \\
$>4$ unprotected acts & $70 \%$ & $64 \%$ & $77 \%$ & $2.64(1.36-5.13)$ \\
Age $<19$ & $35 \%$ & $56 \%$ & $33 \%$ & $2.88(1.79-4.63)$ \\
Ix prior STDs & $25 \%$ & $34 \%$ & $39 \%$ & na \\
Current illicit drug use & $7 \%$ & $\mathbf{1 6 \%}$ & $21 \%$ & $\mathbf{n a}$ \\
\hline
\end{tabular}

Undesired pregnancy had the highest relative risk for STD reinfection at 0-12 months [RR $3.26(1.24-8.56)$ ], as compared to desired pregnancy [nonpregnant vs. desired pregnancy, RR $2.02(0.92-$ 4.45)]. Age < 19 was also highly associated with $0-12$ month reinfection rates, whereas study group, current drug use, history of prior STDs and recruitment source did not enter the logistic model. Still having sex with father of child, no condom use, and $\%$ of acts protected did not differ by pregnancy status. There were no significant differences between cases where the woman desired abortion as compared to the family.

Conclusions: Simple behavioral and sexual risk factors do not adequately explain the differences in STD recurrence rates between desired and undesired pregnancies. Use of more complex behaviora variables which combine individual factors to account for context may be required to understand the differences noted.

\section{CHLAMYDIA PNEUMONIAE SEROPOSITIVITY AND PREECLAMPSIA}

RP Heine; JM Roberts; RB Ness. Magee-Womens Research Institute and Department of Obstetrics, Gynecology and Reproductive Sciences, University of Pittsburgh, Pittsburgh, PA

Objective: Preeclampsia and atherosclerosis are conditions characterized by endothelial cell dysfunction. Infection with Chlamydia pneumoniae (CP), a common cause of community acquired pneumonia, is associated with atherosclerosis. We sought to determine if the seroprevalence of $\mathrm{CP}$ was increased in women with preeclampsia.

Study Design: Serum samples were obtained on 37 patients with preeclampsia and 37 control patients. Concentrations of IgG IgM and IgA antibody to CP, Chlamydia trachomatis (CT) and Chlamydia psittaci (CPS) were determined by microimmunofluorescence. Results were compared using ${ }^{2}$ or Fishers exact test where appropriate. Logistic regression was performed to control for maternal age.

Results: CP IgG serology was positive in $25 / 37(68 \%)$ of preeclamptic patient versus $15 / 37$ (41\%) of controls $(P<0.05$ OR $3.056 \mathrm{CI} 1.18-$ 7.91). This increased risk of IgG seropositivity remained significant after adjustment for maternal age (OR - 3.3, Cl 1.2-9.5) and was consistent at all antibody titer levels. The seroprevalence of CP-IgM, CP-IgA did not differ between groups. Seropositivity to CT and CPS were similar between groups making cross-reactivity unlikely.

Conclusions: Preclampsia is associated with an increased seroprevalence of CP-IgG but not IgM or IgA antibody. We speculate that endothelial damage induced by previous infection with CP predisposes patients to manifest clinical symptoms of preeclampsia.

\section{THE CHANGING FACE OF HIV IN AN INDIGENT POP- ULATION 1993-1998}

Jeanne S. Sheffield, Stacia Anderson, Barbara McElwee, Claire Corley, Donald D. McIntire, George D. Wendel Jr. Dept. Ob/Gyn, Univ. TX Southwestern Medical Ctr., Dallas, TX

Objective: To review the demographic characteristics, risk factors, treatment and pregnancy outcomes in our HIV-positive pregnant population over a 6 year period.

Study Design: Retrospective chart review of all HIV-positive pregnant women receiving prenatal care from January 1, 1993 through February 3, 1998. The following factors were assessed: demographics, HIV diagnosis and disease risk factors, anti-retroviral treatment, vertical transmission rate and pregnancy complications.A computerized database was developed and statistical analysis was performed 
using Pearson Chi-square, Mantel-Haenszel Chi-square for trends and Student-Newman-Keuls test.

Results: 278 pregnancies complicated by maternal HIV infection were ascertained during the study period: $44(16 \%)$ resulted in abortion. The mean maternal age was 24.7 years ( 5.9 years). $72 \%$ of the women were African-American, 15\% Hispanic and 13\% Caucasian. 77 women (28\%) were nulliparous and $224(80.6 \%)$ received prenatal care. 122 women (44\%) were diagnosed with HIV prior to pregnancy, 117 women (42\%) during pregnancy and 19 women $(7 \%)$ at the time of delivery. Overtime, a significantly higher percentage of women were diagnosed prior to pregnancy $(P=0.02)$. The most common risk factor for disease acquisition was heterosexual contact $(79 \%)$. IVDA was second at $14 \%$. There were no significant differences between the races. Medication usage has significantly changed: AZT use in 1993 was $9 \%$ and by $199871 \%$ of patients received AZT $(P=0.001)$. Proteases inhibitor usage and multiple drug therapy has also increased $(P=0.001)$. The number of women diagnosed with AIDS has increased over the study period $(P=0.01)$. Mean CD4 counts and viral titers have not changed over the study period. 152 women ( $73 \%)$ delivered vaginally and 55 women $(27 \%)$ delivered by cesarean section. The mean EGA at delivery was 37.9 ( 3.2 ) weeks with $20 \%$ delivering $<36$ weeks. Mean birthweight was 3002 ( 1322 ) grams with $20 \%<2500$ grams. $6.7 \%$ women developed chorioamnionitis. During the study period, 15 infants $(6.8 \%)$ were diagnosed with HIV, 9 prior to ACTG 076 AZT recommendations. In 1998, there was a 3\% vertical transmission risk. Postpartum complications did not significantly change over the study period.

Conclusions: Over the 6 year study period, the demographic characteristics in the HIV positive pregnant population have not changed. More women were presenting for prenatal care with a diagnosis of HIV and an increasing number of women were on multiple drug therapy. Subsequently, the vertical transmission rate has dramatically decreased.

\section{EFFECT OF METRONIDAZOLE ON THE GROWTH OF LACTOBACILLI SPECIES IN VITRO}

JoseA. Simoes, ${ }^{1,2}$ Alla A. Aroutcheva, ${ }^{1}$ Susan Shott, ${ }^{,}$Sebastian Faro' 'Rush-Presbyterian-St. Luke's Medical Center, Chicago, IL; ${ }^{2}$ State University of Campinas (Unicamp), Brazil

Objectives. To assess in vitro effect of different concentrations of metronidazole on the growth of different species of Lactobacillus. Study Design. The in vitro activity of metronidazole was evaluated against eight different Lactobacillus strains (six vaginal clinical isolates and two ATCC strains). Minimum inhibitory cconcentration (MIC) were determined by broth microdilution method. The medium used was Mann-Rogosa-Sharp (MRS) broth and the assayed dilutions of metronidazole varied from $1 \mathrm{~g} / \mathrm{ml}$ to $7000 \mathrm{~g} / \mathrm{ml}$. The optical density of each tested sample was measured automatically at 4-hour intervals for 24 hours in a Bioscreen CAnalyzer System (Labsystems, Finland). Statistical analyses were performed by the Freidman Test. Results. The growth of all lactobacilli strains was completely inhibited with metronidazole concentrations of 5000,6000 and $7000 \mathrm{~g} / \mathrm{ml}$. In concentrations from 1000 to $4000 \mathrm{~g} / \mathrm{ml}$ the inhibition was partial but also statistically significant. Interestingly, with metronidazole concentrations of 128 and $256 \mathrm{~g} / \mathrm{ml}$ a significant stimulation effect on the lactobacilli growth rate was observed after 24 hours $(P=0.025$ and 0.005 , respectively). No significant differences were found between the control and metronidazole concentrations of $64 \mathrm{~g} / \mathrm{ml}$ or less on the lactobacilli growth.

Conclusions. Concentrations of metronidazole D $500 \mathrm{~g} / \mathrm{ml}$ inhibited the growth of Lactobacillus. At concentrations of $>1000<5000 \mathrm{~g} /$ $\mathrm{ml}$, metronidazole $\mathrm{D}$ exhibited partial inhibition and at concentrations $<256128 \mathrm{~g} / \mathrm{ml}$, it stimulated growth of Lactobacillus. This data may offer insight into why intravaginal metronidazole is not more effective in the treatment of bacterial vaginosis.

\section{CHANGES IN SERUM ACROSS THE MENSTRUAL CYCLE - IS THE RISK FACTOR FOR GONOCOCCAL PID?}

Stella Nowicki, Audrey Hart Van-Tassell, Bogdan Nowicki, UTMB, Galveston, TX

Objectives: The purpose of this study was to determine whether the risk of PID development during menses could be effected by lower bactericidal activity of normal human serum (NHS) during the onset of menstrual cycle.

Study Design: NHS from women of reproductive age was collected from each week of menstrual cycle. Bactericidal activity of NHS samples against four different strains of $N$. gonorrhoeae was evaluated. CH50 was measured to evaluate changes in complement activity of NHS during the menses. Level of $\mathrm{Cl} q$ and interaction of $N$. gonorrhoeae with $\mathrm{Clq}$ in NHS in each sample was evaluated by Eliza and immunoblotting.

Results: Bactericidal activity of NHS from each week was different. Combined results showed significant differences in bactericidal activity of serum between days 1 (the onset of the cycle) and 14 (midcycle) for all strains $\left(\begin{array}{ll}P \quad 0.0002\end{array}\right)$. The difference between day 7 and 14 , and between 14 and 28 , was also significant. The CH50 value decreased during menses, while $\mathrm{Clq}$ level and $\mathrm{Clq}$ binding to $N$. gonorrhoeae decreased in the middle of cycle but increased during menses. These results are consistent from month to month for tested individuals.

Conclusions: This is a first evidence that bactericidal activities of NHS are changeable during menstrual cycle. Complement activity and level of $\mathrm{Clq}$ in NHS is also effected by hormonal changes during menstrual cycle. Increased C1q levels in NHS and Clq binding to $N$. gonorrhoeae during menses could be accounted for decrease bactericidal activity of NHS against $N$. gonorrhoeae. Therefore the risk of PID development during menses could be effected by changes in complement of NHS that allows $N$. gonorrhoeae increase their virulence and survive menstrual bleeding.

This data was partially published (JAMA 2000;283(10):1291-1292.)

\section{COLCHICINE PREVENTS ASCENDING UROGENITAL IN- FECTION OF INVASIVE DR FIMBRIATED ESCHERICHIA COLI IN PREGNANT RATS}

Rangaraj Selvarangan, Pawel Goluszko, Jyotsana Singhal, Stella Nowicki, Bogdan NowickiOb\&Gyn, University of Texas-Medical Branch, Galveston, TX

Objective: Dr fimbriated E. coli represent a select group of strains associated with gestational pyelonephritis in pregnant women. We hypothesize that the unique invasive property of $\mathrm{Dr}+E$. coli may allow it to cause ascending urogenital infection in pregnant host, enabling them to gain access to renal interstitium rich in Dr receptors. Method: We developed an non-invasive model of ascending vaginal colonization in day 18 pregnant Sprague-Dawley rats. The role of invasion in the pathogenesis of gestational pyelonephritis was characterized using an invasive $\mathrm{Dr}+E$. coli pyelonephritis strain $\mathrm{IH} 11128$ and its isogenic non-invasive Dr- E. coli mutant Dr14 . Cotton swabs soaked with $0.2 \mathrm{ml}$ of the bacteria were placed in the vagina of pregnant rats. The following day the rats were sacrificed and 
urogenital tissues isolated aseptically for quantitative bacterial cultures. Colchicine, a microtubule depolymerizing agent has been shown to inhibit entry of Dr+E. coli into cultured epithelial cells. Hence we tested the ability of colchicine to inhibit the spread of infection in the pregnant rat.

Result: Dr+E. coli pyelonephritis strain IH11128 but not its isogenic Dr- E. coli mutant Dr 14 was able to ascend from vagina and spread to the urogenital tissues such as uterus, placenta, fetus, and kidney, $24 \mathrm{hr}$ postinfection $\left(\begin{array}{ll}P & 0.05\end{array}\right)$. The ascending infection was blocked by pretreatment of pregnant rats with colchicine orally at $5 \mathrm{~g} / \mathrm{ani}$ $\mathrm{mal} /$ day for two consecutive days. Colonization of the urogenital tissues in colchicine treated group was significantly reduced in comparison with the untreated group $\left(\begin{array}{ll}P & 0.05\end{array}\right)$. Dr+E. coli were found to attach specifically to cryostat sections of pregnant rat kidney and genital tract which expressed high density of receptors for Dr adhesin. Conclusion: Our results provide evidence that Drt E. coli are capable of invasive spread in the pregnant host and this process may be selectively blocked by colchicine. The involvement of specific receptor-ligand interaction in the pathogenesis of gestational pyelonephritis caused by invasive Dr+ $E$. coli is described.

VAGINAL FLUID PH TESTING IS AN EFFECTIVE WAY TO IDENTIFY PRETERM BIRTH-LINKED LOWER REPRODUCTIVE TRACT INFECTION IN PREGNANCY: A BAYSIAN ANALYSIS

Janice I French, James A. McGregor, James Caillouette. Denver Health Medical Center, University of Colorado School of Medicine Denver, $\mathrm{CO}$ and Pasadena, $\mathrm{CA}$

Goal: Abnormal vaginal/cervical microflora are associated with increased risks of adverse pregnancy outcomes. We evaluated midvaginal $\mathrm{pH}$ as a simple, easy, inexpensive "point of care" means to identify asymptomatic women 1) who can benefit from "screen and treat" approaches to reproductive tract infection in pregnancy, and 2) who may be at relatively low risk of infection.

Method: Women were prospectively evaluated in first or second pregnancy trimesters for vaginal $\mathrm{pH}$ using (ColorpHast) paper and multiple microbiologic abnormalities: bacterial vaginosis (BV), trichomoniasis (TV), chlamydia (CT) infection, gonorrrhea (GC), or candidiasis. Standard microbiological tests were performed.

Results: 1749 Denver subjects were evaluated. Fifty seven percent of subjects were women of color. Women with study microbial conditions commonly had $\mathrm{pH}>4.5$; i.e., BV: $92 \%$, TV: $71 \%$, CT: $57 \%$, and GC: $75 \%(P<0.001)$. Relative risks (RR) of identifying study conditions were increased if $\mathrm{pH}>4.5 ; \mathrm{VV}, \mathrm{CT}$, or TC (RR 3.4; $95 \% \mathrm{CI} 1.5-8.1$ ). Among mothers, $\mathrm{pH}>4.5$ was associated with a $32.3 \%$ overall chance of positive microbial finding, versus $\mathrm{pH} \quad 4.5$ (a) $3.6 \%$ (RR 0.1 ). $\mathrm{pH}>4.5$ was sensitive $(92 \%)$ and specific $(92 \%)$ for diagnosis of both $\mathrm{BV}$ and combined infections (92\%). Among these asymptomatic women, $\mathrm{pH}<4.5$ was associated with NPV of $>$ $97 \%$ for each test condition, except for yeast.

Conclusion: Determination of mid-vaginal pH is a simple, easy, and inexpensive means to identify pregnant women with asymptomatic BV or combined cervicovaginal infections. Sensitivity was $>97 \%$ for test conditions, except for yeast. NPV exceeded $97 \%$ for all test conditions, except yeast. Provider, or possibly patient, initiated detection of mid-vaginal $\mathrm{pH}>4.5$ can be a sensitive means to detect symptomatic mothers who can be selectively tested or retested for $\mathrm{BV}, \mathrm{CT}, \mathrm{TV}, \mathrm{GC}$, or combinations of these infections in pregnancy.
DIFFERENTIAL EFFECTS OF ANTIMICROBIALS ON REPRODUCTIVE TRACT MICROORGANISMS: A NEW PARADIGM FOR TREATMENT OF PRESUMED INTRAUTERINE INFECTION

JA McGregor, JI French, University of Colorado School of Medicine, Denver Health Medical Center, Denver, CO

Objectives: Assess effects of antimicrobials commonly used in obstetrical practice for treatment of possible intrauterine infection on selected genitourinary microorganisms. Some antibiotic-microbe interactions may paradoxically cause increase of virulence release in reproductive tract tissues.

Method: Submicrobial inhibitory (sub-MIC), inhibitory (MIC), and bactericidal (MBC) concentrations of antimicrobial commonly used to treat intrauterine infection were evaluated with aerobic microorganisms recovered from intrauterine sources. Levels of protease released from test microbe were evaluated using dye releasing protease substrate.

Results: Patterns of bacterial protease release by test microbes in differing antimicrobial concentration differed by antimicrobial (i.e., beta lactam vs. clindamycin or erythromycin) and by the microorganisms tested 1. Sub-MIC, MIC, and MBC of test antimicrobials were associated with: 1) suppression, 2) enhanced release or 3) no effect on protease release.

Conclusion: Differing antimicrobial concentrations (sub-MIC, MIC, and $\mathrm{MBC}$ ) were associated with release, suppression, or no effect on test microbe protease release. Release of putative virulence factors such as protease by differing antimicrobial used in treating decidual or trophoblast infection may beneficially or adversely effect local tissues release of virulence factors. Antimicrobial treatments with bactericidal antimicrobials may cause temporary increased microbial virulence in local tissues.

DIAGNOSIS OF BACTERIAL VAGINOSIS EARLY IN GESTATIONAL CORRELATES WITH PRETERM BIRTH

JI French and JA McGregor, University of Colorado School of Medicine, Denver Health Medical Center, Denver, CO

Objectives: Analyze effects of gestational age (GA) at time of diagnosis of bacterial vaginosis (BV) using published prospective cohort studies.

Method: We analyzed 10 cohort studies performed in Denver and comparable published data from other centers worldwide in order to correlate gestational age at diagnosis with risks of subsequent preterm birth ( 37 weeks).

Results: We secondarily evaluated these studies systematically comparing means and $95 \%$ confidence intervals for each study, stratified for gestational age at time of diagnosis.

Conclusion: 1) PTB is associated with testing and recognition of $\mathrm{BV}$ earlier rather than later in pregnancy. We speculate that 1) earlier identification of BVC allows for first and second trimester losses and preterm births to be more accurately measured and 2) presence of bacterial vaginosis early in pregnancy, or possibly prior to conception, is associated with risks of prematurity in susceptible mother-fetus pairs.

These findings confirm the importance of early pregnancy evaluation for bacterial vaginosis and confirm observation that treatment for $\mathrm{BV}$ in late pregnancy is likely to be less effective than early treatment. 


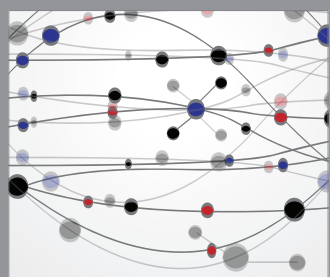

The Scientific World Journal
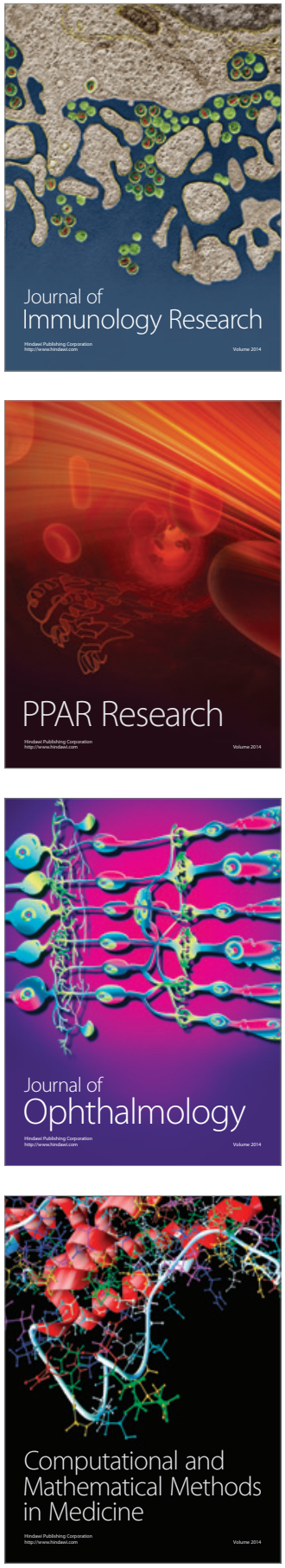

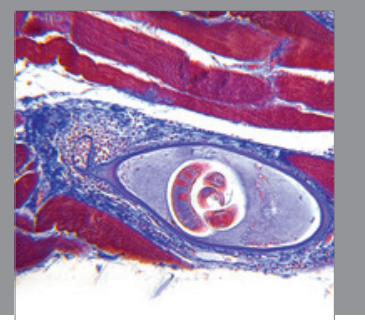

Gastroenterology

Research and Practice
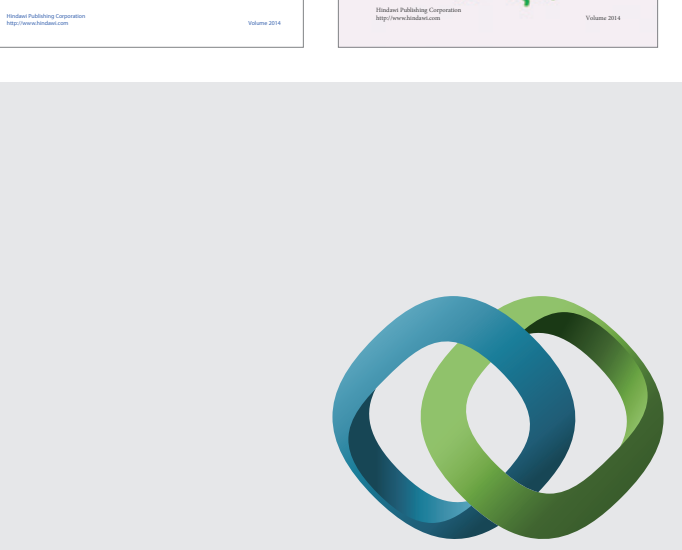

\section{Hindawi}

Submit your manuscripts at

http://www.hindawi.com
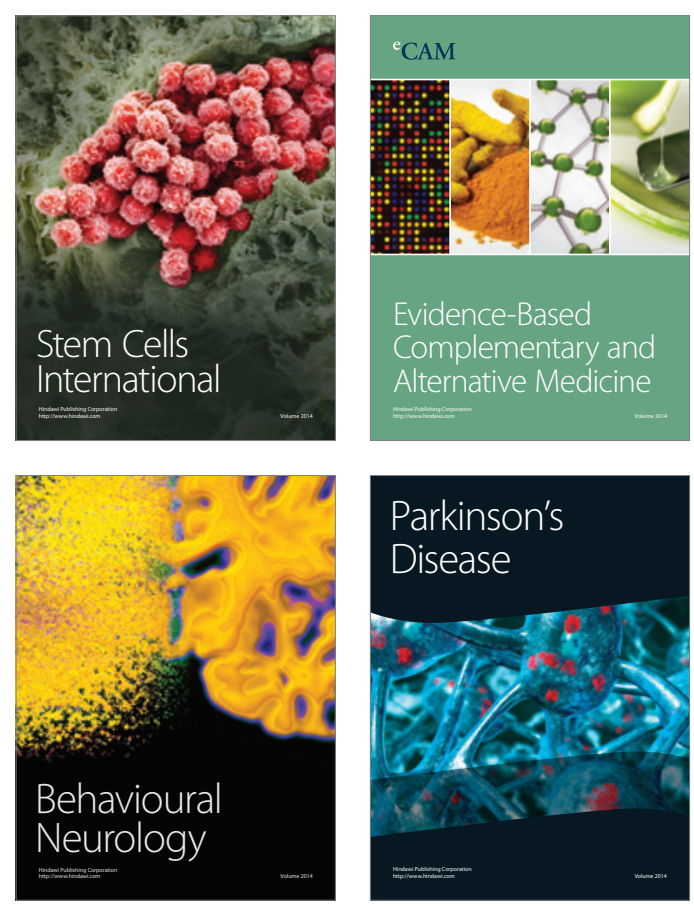

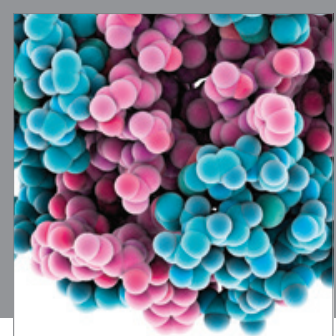

Journal of
Diabetes Research

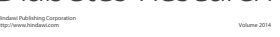

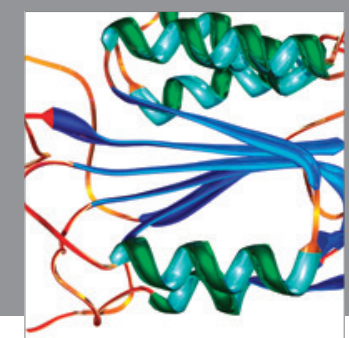

Disease Markers
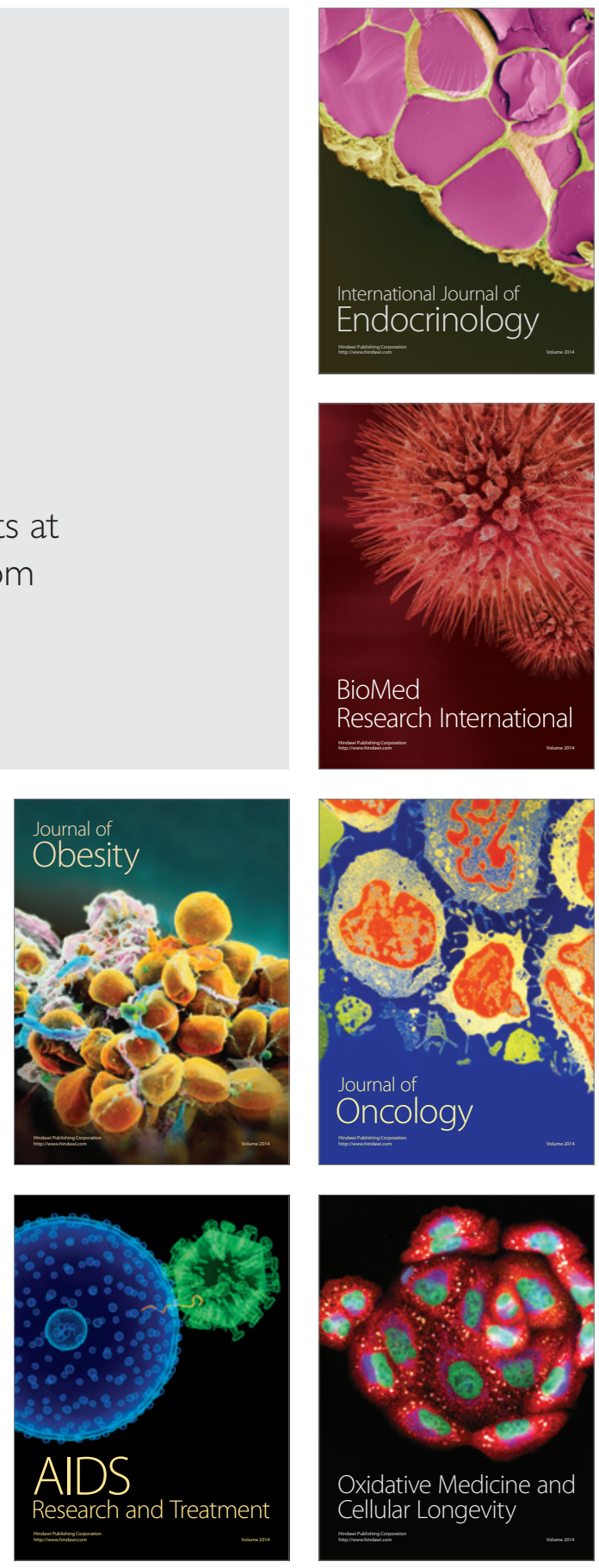